Eleventh Floor, Menzies Building

Monash University, Wellington Road

CLAYTON Vic 3800 AUSTRALIA

Telephone:

(03) 9905 2398, (03) 99055112

Fax:

(03) 99052426

e-mail:

Internet home page: from overseas:

61399052398 or

61399055112

61399052426

impact@buseco.monash.edu.au http//www.monash.edu.au/policy/

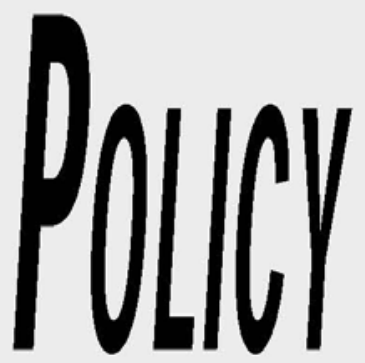

\title{
Modelling Value-Added Tax in the Presence of Multiproduction and Differentiated Exemptions
}

by

JAMES GIESECKE

Centre of Policy Studies

Monash University

AND

NHI HOANG TRAN

Centre of Policy Studies

Monash University

General Paper No. G-182 February 2009

ISSN 10319034

ISBN 0732615895

The Centre of Policy Studies (COPS) is a research centre at Monash University devoted to quantitative analysis of issues relevant to Australian economic policy. 



\title{
MODELLING VALUE-ADDED TAX IN THE PRESENCE OF MULTIPRODUCTION AND DIFFERENTIATED EXEMPTIONS
}

\author{
James A. Giesecke ${ }^{1}$ and Tran Hoang Nhi \\ Centre of Policy Studies, Monash University, Australia
}

February 2009

\begin{abstract}
We develop a framework for economy-wide modelling of value-added tax systems. Our framework models a number of complexities of VAT systems as they are implemented by tax agencies. In particular, we model multiple rates, multiple exemptions, multiple degrees of refundability across commodity users, and multi-product enterprises. A detailed VAT framework, such as that which we present in this paper, is important for correct modelling of VAT within a general equilibrium model. Such a framework is also of value in correctly calculating the distribution of indirect tax payments in CGE model databases, a prerequisite of accurate welfare impact calculations. We use the model to analyse the effects of simplifying Vietnam's complex VAT system. We simplify the system by moving from three tax rates to one budget-neutral rate, while also removing many discretionary exemptions. We find that the policy lifts real private consumption spending, our welfare measure, by an average of 0.9 per cent over our simulation period, 2008-2018.
\end{abstract}

JEL classification: C68, H25, H21

Keywords: value added tax, dynamic CGE model, Vietnam, indirect tax reform.

${ }^{1}$ Corresponding author. Tel 6139905 9756. Email: James.Giesecke@buseco.monash.edu.au

This paper developed from work undertaken for UNDP-funded project VIE/03/010. We gratefully acknowledge UNDP's financial support for that project, and the cooperation and support of officials and researchers at the Ministry of Finance, Hanoi. The paper has benefited from conversations with Do Ngoc Huynh and his colleagues (Ministry of Finance's Policy Advisory Group), Bui Trinh (Vietnamese General Statistics Office), Nguyen Minh Huong (Vietnamese General Department of Taxation) and Peter Dixon (Monash University). The views expressed in this paper are our own. 
TABLE OF CONTENTS

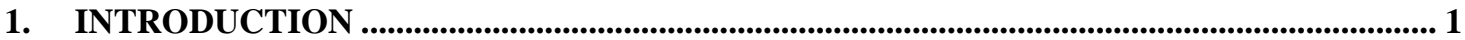

2. A GENERAL FRAMEWORK FOR VAT MODELLING _............................................... 2

3. OVERVIEW OF VIPAG - A DYNAMIC CGE MODEL OF VIETNAM.................................... 6

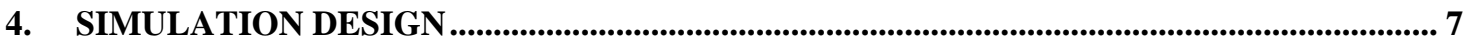

4.1. VAT SIMPLIFICATION: A POLICY OF REVENUE-NEUTRAL VAT RATE EQUALISATION AND EXEMPTION REMOVAL.

4.2. THE COSTS OF VAT COMPLIANCE AND ADMINISTRATION ……................................................. 8

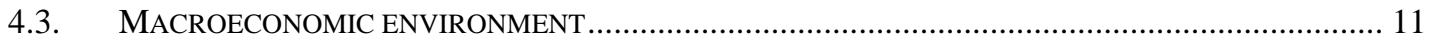

5. THE MACROECONOMIC AND SECTORAL EFFECTS OF VAT SIMPLIFCATION ..... 14

5.1. OVERVIEW: SHORT AND LONG-RUN REAL CONSUMPTION EFFECTS OF VAT SIMPLIFICATION.. 14

5.2. EFFECTS OF COMPLIANCE COST REDUCTION, RATE EQUALISATION AND EXEMPTION REMOVAL16

5.3. EFFECTS OF COMPLIANCE COST REDUCTION ALONE ……………………………………….... 17

5.4. EFFECTS OF RATE EQUALISATION AND EXEMPTION REMOVAL ALONE …………….................... 18

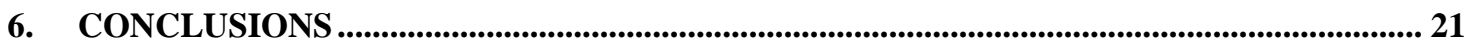




\section{INTRODUCTION}

Since the 1960s, value added tax (VAT) systems have been progressively adopted around the world ${ }^{1}$. The majority of VAT regimes are characterised by a consumption tax base with multiple tax rates, multiple exemptions, and the credit method of tax liability calculation ${ }^{2}$. These VAT characteristics have been incorporated in a number of formal studies on the incidence and economic effects of VAT. However, three important VAT characteristics have yet to be formalised in applied VAT research: multi-production, legislated differences in exemption status, and industry-specific differences in the refundability of VAT paid on inputs to production and investment. The need for careful and detailed treatment of these VAT characteristics is particularly important in disaggregated general equilibrium models. These models are recognised as well suited to analysis of the efficiency effects of tax policies ${ }^{3}$. The modelling of VAT within a general equilibrium framework raises a fourth issue not yet addressed in the VAT modelling literature. Even in highly disaggregated models, commodity and industrial definitions will be, by necessity, aggregates of hundreds or thousands of commodities and industries, each with the possibility of distinct tax rates and exemptions under the relevant nation's VAT statutes. Previous studies have assumed that a commodity is either exempt or taxed. In this paper we provide a comprehensive method for modelling VAT in a detailed economy-wide setting. Our method addresses the four aforementioned VAT features. We apply our technique to the complex Vietnamese VAT system, and examine the macroeconomic consequences of VAT simplification for this developing economy.

In recent years, the Vietnamese indirect tax system has been streamlined and simplified. Nevertheless, a wide range of tax rates and tax exemptions remain. Prior to 1999 a Turnover Tax, levied at rates ranging from $0.5 \%$ to $40 \%$, was levied on gross sales revenue. Criticised for its cascading effects, the Turnover Tax was replaced by a VAT in January 1999. The VAT was initially levied at four rates: 0, 5, 10 and 20 per cent. Since January 2004 the VAT rate structure was reduced to three rates: 0,5 and 10 per cent. Sales to exports and additions to stocks attract the zero VAT rate. So too do sales of certain commodities to all users. These commodities include irrigation services, public administration, education, health care and dwellings services. In general, the 5 per cent rate attaches to unprocessed agricultural commodities at the commercial trading stage, certain primary building materials, chemicals, fertilisers, pharmaceuticals, certain machinery, metal products, animal feed, publishing, water, road transport, rail transport, air transport, scientific services, and cultural services. All other commodities are taxed at 10 per cent. Sales of mining to export are explicitly declared VAT exempt, despite the zero rate applying to export sales. A number of VAT exemptions are also 
made for goods and services deemed either essential or important for economic development. These include raw agricultural materials, imported machinery and equipment used in R\&D and capital formation, health and education services, public broadcasting, cultural events and sanitation works.

With its many rates and exemptions, the Vietnamese VAT system is complex. The literature on indirect taxation recognises that this imposes two economic costs. First, it creates allocative efficiency losses, via its distorting effects on relative prices ${ }^{4}$. Second, it creates technical efficiency losses, because complexity adds to the VAT compliance and enforcement burden $^{5}$. The presence of these costs suggests that welfare gains are available from a revenueneutral simplification of the present system. In this paper, we explore the gains for Vietnam from a move to a single VAT rate that is revenue neutral in the presence of simultaneous removal of discretionary VAT exemptions. We do this with a dynamic CGE model of Vietnam that contains explicit modelling of the complexity of the Vietnamese VAT system. To our knowledge, this is the most detailed economy-wide modelling of VAT undertaken for any economy, developing or developed. We find that the allocative efficiency gains from VAT simplification are small, particularly when compared with the effects of compliance costs. We find that a feature of the present Vietnamese VAT system is taxation of capital accumulation. Our policy of equalised VAT rates and removal of policy exemptions reduces capital taxation. As such, the policy promotes capital accumulation. This is an important source of potential gain for Vietnam.

The remainder of the paper is structured as follows. In Section 2 we present a general framework for modelling value-added tax in the presence of multi-production, differentiated rates and differentiated exemptions. We implement this method for Vietnam, integrating our VAT modelling framework within a large-scale dynamic general equilibrium model. Section 3 provides an overview of this model, VIPAG ${ }^{6}$. Section 4 describes simulation settings. Section 5 discusses results and Section 6 concludes the paper.

\section{A GENERAL FRAMEWORK FOR VAT MODELLING}

The ideal VAT regime, imposing on an economy the lowest level of distortions and compliance costs, is that with a single rate on all domestic sales, a zero-rate on exports, and no exemptions (see Tait, 1988 and Ebrill et al., 2001). Under the ideal VAT regime, the VAT is equivalent to a consumption tax: producers pay VAT on their outputs, but fully reclaim VAT paid on their intermediate inputs. The effective tax rates on producers are thus zero. As such, the tax creates no cascading effect through production chains. The effective tax rates on final consumers are the same as the legislated tax rates. This is the type of VAT often 
modelled in early general equilibrium studies (see, for example Ballard et al., 1987a; Ballard at al., 1987b; Kehoe et al., 1988). It is also typically assumed by statisticians in compiling input-output tables, resulting in zero values for all cells in the tax matrix for intermediate usage and capital formation.

In practice, VAT systems contain exemptions. Exemptions are often granted to basic goods (such as certain foods, medicines, education and healthcare services) and hard-to-tax services (such as housing, finance and insurance). Extensive discussions on these issues and their effects on the economy can be found in Tait (1988) and Ebrill et al. (2001). Producers of exempted goods do not charge VAT on their outputs, but they cannot obtain credits for VAT paid on their inputs. These input taxes are passed on to users of the exempt commodity, irrespective of whether they are a final user or another producer. This creates tax cascading effects, with positive effective VAT rates faced by all producers using the exempt goods. This problem is well-recognised in the VAT literature. It was first explored analytically in Gottfried and Wiegard (1991), who assume that exemptions apply to all users. Later VAT researchers have adopted their method (Marks, 2005; Toh and Lin, 2005).

There are other well-known features of implemented VAT systems that do not yet appear in the formal VAT modelling literature. Our VAT modelling method addresses these features. First, many firms produce multiple commodities. Firms producing both taxable and exempt goods can reclaim only taxes paid on inputs to production of taxable goods. Second, exemptions are often granted to some users but not others. Third, while most industries may receive tax credits on inputs to their capital formation, others may not. As we shall see below, with this complexity, effective VAT tax rates on production and capital formation depend not only on legislated VAT rates, but also on the input structure of production and capital formation, the commodity composition of output, and the structure of commodity sales. A fourth issue arises in the application of published supply/use data in VAT modelling. Published data, even with very high levels of commodity and user detail, will aggregate transactions with different tax and exemption statuses under the legislated VAT code. Previous studies have assumed that a commodity is either exempt or not, disregarding the practical consequences of this assumption for applied tax work. We describe below a method that addresses these four issues, and describe its implementation for our Vietnamese tax simplification study.

We assume an economy of $M$ commodities and $U$ agents. The $U$ agents are comprised of: $N$ industries, $K$ capital creators, and $F$ final demanders. The economy and its VAT regime have the following features: 
1. Multi-production. We represent multi-production via $S O_{c, j}$, the share of total sales of industry $j(j \in N)$ represented by sales of commodity $c(c \in M)$. In our VIPAG implementation, $M=113$ and $N=113^{7}$. We evaluate $S O_{c, j}$ using VIPAG's MAKE matrix.

2. Differentiated legislated VAT rates. We represent differences in legislated VAT rates across commodities and users via $L R_{c, u}$, a matrix of legislated VAT rates on sales of commodity $c(\mathrm{c} \in \mathrm{M})$ purchased by user $u(\mathrm{u} \in \mathrm{U})$. In VIPAG, $U=230$, comprised of 113 industries $(N=113), 113$ capital creators $(K=113)$ and four final users, households, export, government and stocks $(F=4)$. We evaluate the $113 \times 230 L R_{c, u}$ matrix for VIPAG through careful inspection of the Vietnamese tax code (Ministry of Finance 2007a, National Assembly 2003). Typical VIPAG values for $L R_{c, u}$ are 0, 0.05 and 0.10 .

3. Differentiated VAT exemptions. We model exemptions via $E X_{c, u}$, a coefficient measuring the share of sales of commodity $c(c \in M)$ to user $u(\mathrm{u} \in \mathrm{U})$ that are VAT exempt. For most flows, $E X_{c, u}$ is zero. $E X_{c, u}$ has a non-zero value where the tax code exempts from VAT some or all of the sales of commodity $c$ to user $u$. For full exemption, $E X_{c, u}=1$. For partial exemption, $0<E X_{c, u}<1$. The latter reflects aggregation. For example, many countries exempt textbooks. But in most models, textbooks are just part of the broader commodity "publishing". We assume that if textbooks comprise 40 per cent of "publishing" sales to user $u$, then $E X_{\text {publishing }, u}=0.4^{8}$.

4. Differentiated VAT refundability on VAT paid on inputs to capital formation. We use the parameter $\phi_{c, j}^{(2)}$ to denote the proportion refunded of VAT paid by industry $j(\mathrm{j} \in K)$ on purchases of $c(\mathrm{c} \in \mathrm{M})$ for capital formation. Most VAT systems provide for full refund of VAT paid on inputs to capital formation. Hence for most $c, j, \phi_{c, j}^{(2)}=1$. However an important exception is construction of dwellings. Consistent with long-run input-taxation of dwellings services, most VAT systems provide no refund of VAT paid on inputs to housing construction. This is true of the Vietnamese VAT system. The Vietnamese system also disallows VAT refunds on specialised equipment and machinery used in capital formation by public administration, health and education. 
Having specified and evaluated $S O_{c, j}, L R_{c, u}, E X_{c, u}$ and $\phi_{c, j}^{(2)}$ we can now define $E R_{c, u}$, the effective VAT rate applying on purchases of commodity $c$ by user $u$. For non-business users ( $u \in F$ ), we calculate the effective VAT rate as:

$$
E R_{c, u}=L R_{c, u} \times\left[1-E X_{c, u}\right] \quad(c \in M, u \in F)
$$

For producers, calculation of the effective tax rate paid by industry $j(j \in N)$ on purchases of input $c(c \in M), E R_{c, j}$ is complicated by two things: the refundability of VAT paid on inputs to current production, and the multiproduction structure of the economy.

At first, when producer $j$ buys input $c$, it must pay a VAT rate equivalent to the legislated rate less the exemption proportion applicable to $c$ and $j$, that is, $L R_{c, j} \times\left(1-E X_{c, j}\right)$. Industry $j$ can then reclaim this tax, but only to the extent input $c$ is used to produce non-exempt goods. We define a refund factor, $\phi_{j}^{(1)}$, as the proportion of industry $j$ 's VAT payments on inputs to production that is refunded by the tax authority. To calculate $\phi_{j}^{(1)}$ we need to look at two dimensions of industry j's sales: what it produces, and to whom it sells. Data on the first dimension is provided by $S O_{c, j}$. For the second dimension, we introduce $S S_{c, u}$, the share of total sales of commodity $c$ sold to user $u$. We can evaluate $S S_{c, u}$ from row shares in the CGE model's input-output database. We can now define $\phi_{j}^{(1)}$ as:

$$
\phi_{j}^{(1)}=\sum_{c \in M} \sum_{u \in U} S O_{c, j} S S_{c, u}\left[1-E X_{c, u}\right] \quad(j \in N)
$$

With $\phi_{j}^{(1)}$ defined, we calculate the effective VAT rates paid by industry $j$ as:

$$
E R_{c, j}=L R_{c, j} \times\left[1-E X_{c, j}\right]\left[1-\phi_{j}^{(1)}\right] \quad(c \in M, j \in N)
$$

Having already defined $\phi_{c, j}^{(2)}$, the refund factor on purchases of $c$ by $j$ for capital formation, we calculate the effective VAT rate on inputs to investment as:

$$
E R_{c, j}=L R_{c, j} \times\left[1-E X_{c, j}\right]\left[1-\phi_{c, j}^{(2)}\right] \quad(c \in M, j \in K)
$$

Equations (E1) to (E4) are our VAT model. The VAT model serves two purposes. First, it is required for construction of the CGE model's database. We require a M x U matrix of VAT payments that is consistent with both published input-output data and the tax code. Equations (E1) to (E4) allows us to calculate this. Second, (E1) to (E4) become part of the CGE model's theory. In placing (E1) - (E4) in the model, we now endogenously calculate: (i) effective 
VAT rates applying to flows of commodity $c$ to user $u,\left(E R_{c, u}\right)$; and (ii) current production refund factors $\left(\phi_{j}^{(1)}\right)$, given (a) exogenously specified values for legislated VAT rates $\left(L R_{c, u}\right)$; (b) exemption factors $\left(E X_{c, u}\right)$; and (c) capital formation refund factors $\left(\phi_{c, j}^{(2)}\right)^{9}$.

As apparent from the above equations, in the presence of exemptions the effective VAT rates on final consumption can differ from the legislated rates, and VAT rates on inputs to production and investment can differ from zero. Our calculations show that in 2005 only 62.6 per cent of VAT collections come from final consumption. VAT collections from production and investment comprise 29.4 and 8.0 per cent respectively ${ }^{10}$.

\section{OVERVIEW OF VIPAG - A DYNAMIC CGE MODEL OF VIETNAM}

Our aim is to assess the macroeconomic and sectoral consequences of Vietnamese VAT reform. To do this, we require an economy-wide model. Since the VAT model described in Section 3 requires high levels of commodity and user detail, our economy-wide model must also possess such detail. Hence we use VIPAG, a dynamic CGE model of the Vietnamese economy possessing high levels of commodity and user disaggregation. VIPAG is a Vietnamese implementation of the well-known MONASH model (Dixon and Rimmer 2002). Giesecke and Tran H.N. (2008a, 2008b) document the Vietnam implementation of the model. However, readers of this paper do not need to be familiar with the details of these references, since our discussion of results in Section 5 relies on standard economic mechanisms. We provide a brief overview of VIPAG below.

VIPAG has 113 industries and 113 commodities. Three primary factors are identified (labour, capital and land) with labour further distinguished by skill. The model has one representative household and one central government. Optimising behaviour governs decision-making by firms and households. Each industry minimises unit costs subject to given input prices and a constant returns to scale (CRS) output function. Household demands are modelled via a representative utility-maximising household. Units of new industry-specific capital are cost minimising combinations of Vietnamese and foreign commodities. Imperfect substitutability between imported and domestic varieties of each commodity is modelled using the Armington CES assumption. The export demand for any given Vietnamese commodity is inversely related to its foreign-currency price. The model recognises consumption of commodities by government, and the details of direct and indirect taxation instruments. It is assumed that all sectors are competitive and all markets clear. Purchasers' prices differ from producer prices by the value of indirect taxes and trade and transport 
margins. VIPAG recognises three types of dynamic adjustment: capital accumulation, net liability accumulation and lagged adjustments. Capital accumulation is industry-specific, and linked to industry-specific net investment. Annual changes in the net liability positions of the private and public sector are related to their annual investment/savings imbalances. In policy simulations, the labour market follows a lagged adjustment path. In the short-run, real consumer wages are sticky. Hence short-run labour market pressures mostly manifest as changes in employment. In the long-run, employment returns to basecase ${ }^{11}$, with labour market pressures reflected in changes in real wages.

\section{SIMULATION DESIGN}

\subsection{VAT simplification: a policy of revenue-neutral VAT rate equalisation and exemption removal.}

We investigate a program of simplification of the Vietnamese VAT system. We examine the effects of this policy by comparing the forecast path of the economy with the reform against a basecase forecast path of the economy without the reform. Hence, relative to our basecase forecast $^{12}$, our policy simulation makes the following changes in 2008 :

(i) We remove discretionary VAT exemptions. In terms of equations (E1) through (E4), we reduce the values of selected elements of $E X_{c, u}$.

(ii) All VAT rates are equalised at a single rate, designed to be revenue neutral in the presence of removal of discretionary exemptions. This rate is 8.3 per cent. We calculate this rate in a side simulation (see below). In terms of equations (E1) through (E4), we set all $L R_{c, u}=0.083$.

(iii) We improve primary factor productivity. This reflects our conjecture that removal of VAT exemptions and multiple VAT rates will lower VAT compliance costs.

To calculate the single VAT rate that is revenue neutral in the presence of removal of discretionary policy-related exemptions, we run a side simulation with VIPAG. Holding aggregate VAT revenue exogenous, we force the model to find a single VAT rate consistent with unchanged aggregate VAT revenue, while simultaneously removing discretionary exemptions. As we discussed in Section 2, the present VAT system contains many exemptions. Some relate to the need to input-tax services such as finance and dwellings. Other exemptions are public policy decisions. We remove such discretionary exemptions on:

i. sales of mining to exports; 
ii. fresh food products;

iii. publishing;

iv. sales of transport services to exports;

v. sales of science, technology, education, health, culture and sport, associations, to nongovernment users.

We also introduce refunds on purchases of equipment by health and education for capital formation (in the basecase forecast, VAT paid on such transactions are not refunded, that is, in terms of equation (E4), $\phi_{c, j}^{(2)}=0$ ).

With the above changes, we are still left with a number of exemptions, in particular those related to hard-to-tax services, namely:

i. $\quad$ sales of finance services;

ii. life insurance;

iii. all intermediate inputs to dwellings services;

iv. sales of community services.

We also retain basecase exemptions on sales by industries dominated by many small traders, in particular: agricultural industries, trade, and repairs. As in the basecase, we assume a 50 per cent rate of exemption on such sales, to reflect low registration for VAT among small traders.

Our side simulation indicates that a single VAT rate of 8.3 per cent is revenue-neutral in the presence of the aforementioned changes to exemptions and refund factors. Hence our policy simulation involves making these changes in exemptions and refunds in 2008, while moving all VAT rates to 8.3 per cent. Since this simplifies the VAT system, we conjecture that this will reduce compliance costs. We model lower compliance costs via a change in primary factor productivity calibrated to contribute 0.3 percentage points to real GDP. We outline below our justification for this value.

\subsection{The costs of VAT compliance and administration}

As discussed in Section 1, Vietnam's VAT system is complicated, with three tax rates and numerous exemptions across commodities and taxpayers. In complying with this tax system, businesses and government incur expenses. Following Tran N.B. (2001) and Vaillancourt and Clemens (2008) we refer to these expenses as private-sector compliance costs and public administrative costs. We conjecture that these expenses will be lower under a simpler VAT system. 
There is a common agreement among tax researchers that the simpler a tax system (that is, the fewer the rates and exemptions) the lower will be compliance and administrative costs (see, for example, Tait, 1988; Salvail 1994; Le, 2003). Watanabe and Duong (2006) discuss in detail the costs associated with the multiple rates and exemptions under Vietnam's present VAT system. They argue that additional costs, compared with a simpler system with only one rate and no or very few exemptions, arise from two issues. First, taxpayers producing goods that are both taxable and exempt must not only distinguish taxable and non-taxable sales to calculate VAT payments, they also face a complex input tax credit calculation since VAT refunds can only be sought for tax paid on inputs related to taxable items. Second, both tax payers and tax authorities must identify and apply the correct tax rate on each transaction. Not only does this add to compliance and administration costs, it promotes opportunities for tax fraud. Tax fraud creates additional economic costs, as it diverts private resources towards identifying opportunities for fraud, and public resources towards uncovering fraud and prosecuting its perpetrators.

Since our policy equalises rates and reduces exemptions, we expect compliance and administrative costs to fall. However, there are no independent estimates of the likely size of reductions in such costs for Vietnam. As we shall argue below, we think a plausible estimate of the present level of such costs is around 0.6 per cent of GDP. This is higher than that in other countries with simpler VAT systems. For other countries, VAT compliance and administration costs represent about 0.3 per cent of GDP. In the simulation we report in this section, we assume that VAT simplification will reduce compliance costs by the difference between these numbers, that is, 0.3 percentage points of GDP.

We begin by calculating private sector compliance costs per firm based on an estimate by PriceWaterhouseCoopers and the World Bank (2006). They found that a modest-sized Vietnamese company with 60 employees must spend 300 hours per year on consumption tax compliance activities. Since VAT constitutes the bulk of Vietnamese consumption taxation, and it is the only consumption tax that affects most businesses ${ }^{13}$, we can attribute much of the 300 hours to VAT compliance ${ }^{14}$. This translates to a labour cost of VND 5.6 million per enterprise $^{15}$. Firms also incur intermediate input and capital expenses in complying with the $\mathrm{VAT}^{16}$. We also estimate these expenses at VND 5.6m. per enterprise ${ }^{17}$. Hence we place a typical enterprise's VAT compliance costs at VND 11.3m.

Next, we extrapolate our enterprise costs to the economy-wide level. We put the number of businesses in Vietnam in 2005 at approximately 2.8 million $^{18}$. These businesses differed greatly in size. More than half of businesses had only one employee, a third employed 2-5 
persons, 6 per cent employed 6-50 persons, and only about 1 per cent employed more than 50 persons. Furthermore, not all businesses registered for VAT. To account for these factors, we used the following procedure to estimate aggregate private compliance costs.

First, we divide the compliance cost of VND $11.3 \mathrm{~m}$. per modest-sized business with 60 employees (calculated above) into a fixed and variable cost component ${ }^{19}$. We assume that the fixed cost is 10 per cent of the total cost (VND $1.13 \mathrm{~m}$.). The variable cost depends on the size of businesses, which we proxy by number of employees ${ }^{20}$. The average variable cost per employee is VND $0.17 \mathrm{~m}$. per year $(=(11.3-1.13) / 60)$. Hence the average annual compliance cost for a business with $\mathrm{L}$ employees, registered for VAT, is $1.13+0.17 \mathrm{x} \mathrm{L}$ (VND m.).

Only a certain proportion of firms in each size category have registered for VAT. The smaller a firm, the less likely it is to register for VAT, since compliance costs are relatively high for small firms (Vaillancourt and Clemens, 2008; Tran N.B., 2000, 2001). We assume a registration rate of 100 per cent for businesses with more than 5 employees, 80 per cent for businesses with 4-5 employees, 70 per cent for businesses with 2-3 employees, and 50 per cent for one-employee businesses. Applying this to Establishment Census firm numbers, this results in about 1.7 million VAT payers in 2005, covering 60 per cent of all businesses. This is consistent with Watanabe and Duong (2006), who place the number of VAT payers in 2002 at 1.45 million, covering 54 per cent of all businesses. Multiplying the total number of VAT registered businesses with the average compliance cost per business in each size category, we arrive at total private compliance costs of VND 3.5 trillion. This is 7.6 per cent of 2005 VAT revenue.

VAT compliance and enforcement also involves public costs. We are unaware of such estimates for Vietnam, and there are few studies for foreign countries. An exception is Canada, where Salvail (1994) calculated recurrent public VAT enforcement costs at 3.2-3.6 per cent of VAT revenue. Canada has a simpler VAT system than Vietnam, with only one rate of 7 per cent and few exemptions. On the basis of the Canadian study, we adopt 3.5 per cent as a lower-bound estimate of the public costs of VAT administration in Vietnam ${ }^{21}$.

We estimate private compliance costs at 7.6 per cent of VAT revenue and public costs at 3.5 per cent of VAT revenue. Hence we view 11 per cent of VAT revenue to be a plausible estimate of total (private plus public) compliance costs of the Vietnamese VAT. This is higher than estimates for other countries for which investigations of VAT compliance costs have been undertaken. A recent review of surveys of compliance costs by Vaillancourt and Clemens (2008) found total VAT compliance costs range between 3.7 and 7.3 per cent of total 
VAT collections. Given the relative complexity of Vietnam VAT, our higher estimate appears plausible.

For countries reviewed by Vaillancourt and Clemens (2008) and Tran N.B. (2000), which have simpler VAT systems than that of Vietnam, the average total compliance cost is 0.3 per cent of $\mathrm{GDP}^{22}$. Our estimate for Vietnam is equivalent to 0.6 per cent of GDP. We assume that VAT simplification will reduce Vietnamese compliance costs by the difference between these numbers: 0.3 per cent of GDP. We implement this as a uniform shift in primary factor productivity across all industries (except Dwellings) worth 0.3 percentage points of basecase 2008 real GDP.

\subsection{Macroeconomic environment}

We adopt conventional closure assumptions for all macro variables other than real consumption. Our labour market closure is characterised by short-run stickiness in the real wage, with employment returning to basecase in the long-run. We allow the balance of trade to be endogenous, while accounting for changes in net foreign debt, net foreign interest payments, and gross national disposable income (GNDI). Industry-specific net investment is a positive function of rates of return. Capital stocks in each industry are sticky in the short-run, but adjust via changes in annual net investment to return rates of return towards basecase in the long-run. We expand on our real consumption closure below.

Consumption is often determined in CGE models by:

$$
\mathrm{C}+\mathrm{G}=\Theta \cdot \mathrm{GNDI}
$$

where $\mathrm{C}$ and $\mathrm{G}$ are nominal private and public consumption respectively, $\Theta$ is the average propensity to consume, and GNDI is nominal gross national disposable income. The percentage change form of (E5) is:

$$
\mathrm{C}\left(p_{C}+x_{C}\right)+\mathrm{G}\left(p_{G}+x_{G}\right)=[\mathrm{C}+\mathrm{G}](\vartheta+\text { gndi })
$$

where $x_{C}$ and $x_{G}$ are percentage changes in real private and public consumption respectively, $p_{C}$ and $p_{G}$ are percentage changes in private and public consumption deflators, $\vartheta$ is the percentage change in the average propensity to consume, and gndi is the percentage change in GNDI. We define GNDI as:

$$
\mathrm{GNDI}=\mathrm{GDP}-\mathrm{INT}_{\mathrm{P}}-\mathrm{INT}_{\mathrm{G}}+\mathrm{TRN}_{\mathrm{P}}+\mathrm{TRN}_{\mathrm{G}}
$$


where GDP is nominal GDP at market prices, $\mathrm{INT}_{\mathrm{P}}$ and $\mathrm{INT}_{\mathrm{G}}$ are interest payments on private and public net foreign debt respectively, and $\mathrm{TRN}_{\mathrm{P}}$ and $\mathrm{TRN}_{\mathrm{G}}$ are net foreign transfers to the private and public sectors. The percentage change form of (E7) is:

$$
\text { GNDI gndi }=\mathrm{GDP}\left(p_{\text {gdp }}+x_{g d p}\right)-\mathrm{INT}_{\mathrm{P}} \mathrm{int}_{P}-\mathrm{INT}_{\mathrm{G}} i n t_{G}+\mathrm{TRN}_{\mathrm{P}} \operatorname{trn}_{P}+\mathrm{TRN}_{\mathrm{G}} \operatorname{trn}_{G}
$$

Substituting (E8) into (E6):

$$
\begin{aligned}
& \mathrm{C} x_{C}+\mathrm{G} x_{G}=\Theta\left[\mathrm{GDP} x_{g d p}-\mathrm{INT}_{\mathrm{P}} \text { int }_{P}-\mathrm{INT}_{\mathrm{G}} \text { int }_{G}+\mathrm{TRN}_{\mathrm{P}} \text { trn }_{P}+\mathrm{TRN}_{\mathrm{G}} \text { trn }_{G}\right] \\
& +\Theta \mathrm{I} p_{I}-[1-\Theta]\left\{\mathrm{C} p_{C}+\mathrm{G} p_{G}\right\}+\Theta\left\{\mathrm{X} p_{X}-\mathrm{M} p_{M}\right\}+[\mathrm{C}+\mathrm{G}] \vartheta
\end{aligned}
$$

where $\mathrm{I}, \mathrm{X}$ and $\mathrm{M}$ are nominal investment, exports and imports respectively, and $p_{I}, p_{X}$ and $p_{M}$ are percentage changes in the price of investment, exports and imports respectively.

Equation (E9) is suitable for most simulations, properly capturing the impact on real consumption of changes in the terms of trade, real GDP and net foreign income. Hence it is a commonly-used consumption closure in CGE modelling. However it has two limitations. First, with $\vartheta$ exogenous, deviations in national income will be split between consumption and savings in basecase proportions. As such, deviations in $x_{C}$ and $x_{G}$ will give damped indications of welfare movements. More importantly, with (E9) operational, the real consumption deviation will be damped whenever the price of investment falls strongly relative to the price of consumption ${ }^{23}$. As we shall see in Section 5, just such an outcome is the result of simplification of the Vietnamese VAT system. To let a fall in the relative price of investment affect consumption overlooks that less savings are now required to secure a given real level of investment. To recognise this, we adopt an alternative consumption rule to (E5). We determine real consumption in the policy case by ensuring that real national savings stays on its basecase path. An additional benefit of this approach is that the deviation in real consumption can now be interpreted as a welfare measure. We define real savings $\left(S_{R}\right)$ as:

$$
\mathrm{S}_{\mathrm{R}}=[\mathrm{GNDI}-\mathrm{C}-\mathrm{G}] / \mathrm{P}_{\mathrm{I}}
$$

where $\mathrm{P}_{\mathrm{I}}$ is the investment price deflator ${ }^{24}$.

Substituting (E7) into (E10) and converting the resulting expression to percentage change form, we have:

$$
\begin{aligned}
& \mathrm{S}\left(s_{R}+p_{I}\right)=\mathrm{GDP}\left(p_{G D P}+x_{G D P}\right)-\mathrm{INT}_{\mathrm{P}} i_{P} t_{P}-\mathrm{INT}_{\mathrm{G}} \text { int }_{G} \\
& +\mathrm{TRN}_{\mathrm{P}} \mathrm{trn}_{P}+\mathrm{TRN}_{\mathrm{G}} \mathrm{trn}_{G}-\mathrm{C}\left(p_{C}+x_{C}\right)-\mathrm{G}\left(p_{G}+x_{G}\right)
\end{aligned}
$$


where $\mathrm{S}$ is nominal savings. In the policy case we hold foreign transfers and real public consumption at their basecase levels $\left(\operatorname{trn}_{P}=\operatorname{trn}_{G}=x_{G}=0\right)$. Re-arranging (E11), and dividing through by GDP, we have:

$$
\begin{aligned}
x_{C}= & \left(1 / \mathrm{S}_{\mathrm{C}}\right) x_{G D P}+\left(1 / \mathrm{S}_{\mathrm{C}}\right)\left(\mathrm{S}_{\mathrm{X}} p_{X}-\mathrm{S}_{\mathrm{M}} p_{M}\right)+\left(1 / \mathrm{S}_{\mathrm{C}}\right)\left[\mathrm{S}_{\mathrm{I}}-\mathrm{S}_{\mathrm{S}}\right] p_{I} \\
& -\left(1 / \mathrm{S}_{\mathrm{C}}\right) \mathrm{S}_{\mathrm{INT}_{\mathrm{P}}} i_{P}-\left(1 / \mathrm{S}_{\mathrm{C}}\right) \mathrm{S}_{\mathrm{INT}_{\mathrm{G}}} \text { int }_{G}-\left(1 / \mathrm{S}_{\mathrm{C}}\right) \mathrm{S}_{\mathrm{S}} \mathrm{S}_{R}
\end{aligned}
$$

where $\mathrm{S}_{\mathrm{N}}$ is $\mathrm{N}$ expressed as a share of GDP.

In our VAT simulations, we hold policy-case real savings on its basecase path. That is, the deviation in real savings $\left(s_{R}\right)$ is zero. As such, (E12) determines $x_{C}$ and (E9) determines $\vartheta$. With (E12) operational (that is, $s_{R}$ exogenous), changes in the price of investment $\left(p_{I}\right)$ will have only a small effect on real consumption $\left(x_{C}\right)$ since $\mathrm{S}_{\mathrm{I}} \approx \mathrm{S}_{\mathrm{S}}$.

In using (E12) as the basis for our real consumption decomposition, we go one step further, noting that the two interest payment variables ( $i n t_{P}$ and $i n t_{G}$ ) can be decomposed into a debt and exchange rate term. This proves helpful in Section 5 where we provide a detailed decomposition of our real consumption result. The level of interest paid by agent $a$ on its foreign debt is $\left(\mathrm{INT}_{\mathrm{a}}\right)$ is given by:

$$
\operatorname{INT}_{\mathrm{a}}=\operatorname{NETDEBT}_{\mathrm{a}} \times \mathrm{R}_{\mathrm{a}} / \Phi
$$

where NETDEBT $_{\mathrm{a}}$ is the net foreign debt of agent $a$ in foreign currency terms, $\mathrm{R}_{\mathrm{a}}$ is the interest rate on that debt, and $\Phi$ is the nominal exchange rate (expressed as units of foreign currency per dong). Noting that we assume $\mathrm{R}_{\mathrm{a}}$ is exogenous to our VAT simulation, the percentage change form of (E13) is:

$$
\text { int }_{a}=\text { netdebt }_{a}-\phi
$$

Substituting (E14) into (E12) we have:

$$
\begin{aligned}
x_{C}= & \left(1 / \mathrm{S}_{\mathrm{C}}\right) x_{G D P}+\left(1 / \mathrm{S}_{\mathrm{C}}\right)\left(\mathrm{S}_{\mathrm{X}} p_{X}-\mathrm{S}_{\mathrm{M}} p_{M}\right)+\left(1 / \mathrm{S}_{\mathrm{C}}\right)\left[\mathrm{S}_{\mathrm{I}}-\mathrm{S}_{\mathrm{S}}\right] p_{I}-\left(1 / \mathrm{S}_{\mathrm{C}}\right) \mathrm{S}_{\mathrm{S}} S_{R} \\
& -\left(1 / \mathrm{S}_{\mathrm{C}}\right) \mathrm{S}_{\mathrm{INT}_{\mathrm{P}}} \text { netdebt }_{P}-\left(1 / \mathrm{S}_{\mathrm{C}}\right) \mathrm{S}_{\mathrm{INT}_{\mathrm{G}}} \text { netdebt }_{G}+\left(1 / \mathrm{S}_{\mathrm{C}}\right)\left[\mathrm{S}_{\mathrm{INT}_{\mathrm{P}}}+\mathrm{S}_{\mathrm{INT}_{\mathrm{G}}}\right] \phi
\end{aligned}
$$

In Section 5 we use (E15) to explain our real consumption deviation. Table 1 reports the equation (E15) decomposition. In Table 1, it is clear our decomposition has three dimensions: time $\mathrm{x}$ effect $\mathrm{x}$ component. By time, we mean that since our model is dynamic, we can apply (E15) to any year of our dynamic path. In compiling Table 1, we choose years 1 (2008) and 10 (2018). By effect, we mean the contribution to real consumption made by the 
individual right hand side elements of (E15). These are identified and described in the first column of Table 1. By component, we mean that our VAT simplification program can be viewed as comprised of two components: (i) reduced compliance costs, and (ii) rate equalisation and exemption removal. The contribution to the real consumption deviation made by the two components can be identified by running two simulations: (a) one in which only compliance costs are reduced, and (b) one in which only rates are equalised and exemptions removed. The contributions made by these components are identified in columns (2) and (3) (for 2008) and (6) and (7) (for 2018). Since the model is non-linear, we must also report results for a simulation in which compliance costs are reduced and VAT rates and exemptions are changed simultaneously (Columns 5 and 9$)^{25}$.

\section{THE MACROECONOMIC AND SECTORAL EFFECTS OF VAT SIMPLIFCATION}

\subsection{Overview: Short and long-run real consumption effects of VAT simplification}

In Table 1, we see that the full VAT program lifts real private consumption spending by 0.96 per cent in the short-run, and 0.85 per cent in the long run. (row 8, columns 5 and 9). Approximately 70 per cent of the consumption deviation is due to reduced compliance and administrative costs, with the remaining 30 per cent due to VAT rate equalisation and exemption removal. Here, we summarise the main economic mechanisms responsible for the consumption deviations reported in Table 1. In Sections 5.2 and 5.3 we expand our discussion of results.

Lower compliance and administrative costs contribute to both short-run and long-run real private consumption gains mainly by raising real GDP relative to basecase (row 1, columns 2 and 6). The long-run real GDP contribution to consumption (row 1, column 6) is greater than the short-run contribution (row 1, column 2) because lower compliance costs promote longrun capital accumulation. However this capital is largely financed by foreign borrowing. This accounts for the negative contribution to long-run real consumption made by the private debt effect (row 4, column 6). With lower compliance costs, the terms of trade makes a small positive contribution to real consumption in the short-run (row 2, column 2) but a negative contribution in the long-run (row 2, column 6). In the short-run, reducing compliance costs promotes investment. This causes a positive terms of trade deviation, which contributes 0.03 percentage points to the short-run real consumption deviation (row 2, column 2). However in the long-run, reduced compliance costs lower the terms of trade by expanding the size of the economy. This damps the long-run real consumption deviation (row 2, column 6). 
Table 1: Real private consumption decomposition via Equation (E15) (percentage deviation from basecase)

\begin{tabular}{|c|c|c|c|c|c|c|c|c|c|}
\hline \multirow{2}{*}{\multicolumn{2}{|c|}{ (1) }} & \multicolumn{4}{|c|}{2008} & \multicolumn{4}{|c|}{2018} \\
\hline & & (2) & (3) & (4) & (5) & (6) & (7) & (8) & (9) \\
\hline \multicolumn{2}{|c|}{ Right-hand-side elements of BOTE equation (E15) } & $\begin{array}{r}\text { Compliance } \\
\text { only } \\
\end{array}$ & $\begin{array}{r}\text { Exemptions \& } \\
\text { rates only } \\
\end{array}$ & $\begin{array}{r}\text { Residual } \\
(5)-(2)-(3) \\
\end{array}$ & $\begin{array}{r}\text { Full VAT } \\
\text { Simulation } \\
\end{array}$ & $\begin{array}{r}\text { Compliance } \\
\text { only } \\
\end{array}$ & $\begin{array}{r}\text { Exemptions \& } \\
\text { rates only } \\
\end{array}$ & $\begin{array}{c}\text { Residual } \\
(9)-(6)-(7) S \\
\end{array}$ & $\begin{array}{r}\text { Full VAT } \\
\text { Simulation } \\
\end{array}$ \\
\hline 1. Real GDP effect & $\left(1 / \mathrm{S}_{\mathrm{C}}\right) x_{G D P}$ & 0.66 & 0.00 & 0.00 & 0.66 & 0.75 & 0.26 & 0.00 & 1.01 \\
\hline 2. Terms of trade effect & $\left(1 / \mathrm{S}_{\mathrm{C}}\right)\left(\mathrm{S}_{\mathrm{X}} p_{X}-\mathrm{S}_{\mathrm{M}} p_{M}\right)$ & 0.03 & 0.25 & 0.00 & 0.29 & -0.11 & 0.12 & 0.00 & 0.01 \\
\hline 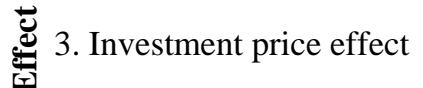 & $\left(1 / \mathrm{S}_{\mathrm{C}}\right)\left[\mathrm{S}_{\mathrm{I}}-\mathrm{S}_{\mathrm{S}}\right] p_{I}$ & -0.01 & -0.05 & 0.00 & -0.06 & 0.00 & -0.05 & 0.00 & -0.05 \\
\hline 4. Private debt effect & $-\left(1 / \mathrm{S}_{\mathrm{C}}\right) \mathrm{S}_{\mathrm{INT}_{\mathrm{P}}} n$ etdebt $t_{P}$ & 0.00 & 0.00 & 0.00 & 0.00 & -0.07 & -0.09 & 0.00 & -0.16 \\
\hline 5. Public debt effect & $-\left(1 / \mathrm{S}_{\mathrm{C}}\right) \mathrm{S}_{\mathrm{INT}_{\mathrm{G}}}$ netdebt $_{G}$ & 0.00 & 0.00 & 0.00 & 0.00 & 0.00 & 0.00 & 0.00 & 0.00 \\
\hline 6. Exchange rate effect & $\left(1 / \mathrm{S}_{\mathrm{C}}\right)\left[\mathrm{S}_{\mathrm{INT}_{\mathrm{P}}}+\mathrm{S}_{\mathrm{INT}_{\mathrm{G}}}\right] \phi$ & 0.02 & 0.05 & 0.00 & 0.07 & 0.00 & 0.03 & 0.00 & 0.02 \\
\hline \multicolumn{2}{|l|}{ 7. Total BOTE equation (15) } & 0.70 & 0.25 & 0.01 & 0.96 & 0.57 & 0.27 & 0.00 & 0.84 \\
\hline \multicolumn{2}{|c|}{ 8. Real private consumption - dynamic CGE model result } & 0.70 & 0.25 & 0.01 & 0.96 & 0.57 & 0.28 & 0.00 & 0.85 \\
\hline
\end{tabular}


VAT rate equalisation and exemption removal contributes about one quarter of a per cent to real private consumption in both the short-run and long-run (row 8, columns 3 and 7). In the short-run, the VAT changes promote consumption largely via higher terms of trade. The VAT changes lower the cost of investment, lifting rates of return and thus lifting investment. In the short-run, this positive investment deviation pushes the balance of trade towards deficit, generating a positive terms of trade deviation. The movement towards trade deficit requires real exchange rate appreciation. This lowers the real burden of Vietnam's foreign liabilities, which are denominated in foreign currency terms. This accounts for the positive contribution of the real exchange rate effect (row 6, column 3). In the long-run, the VAT changes contribute to real consumption largely via higher real GDP (row 1, column 7). Long-run real GDP is higher because the VAT changes promote capital accumulation. The financing of this capital accumulation reduces long-run real consumption by 0.09 per cent (row 2, column 3). The short-run terms of trade contribution (row 2, column 3) exceeds that of the long-run (row 2, column 7) because the VAT changes induce a sharp short-run deviation in real investment. The real investment deviation is attenuated in the long-run by the gradual return of rates of return to their basecase levels.

We expand on these results in Sections 5.2 and 5.3.

\subsection{Effects of compliance cost reduction, rate equalisation and exemption removal}

Charts A1 to A4 report macroeconomic and sectoral impacts of the full VAT simplification program. The program generates positives deviations in real investment, the capital stock and real GDP (Charts A1 and A2). In Chart A2 we see that the policy is strongly investment promoting. Hence in the short-run the policy shifts the balance of trade towards deficit, generating a transitory improvement in the terms of trade (Chart A3). Throughout the simulation period, real private consumption is significantly above basecase (Chart A2). Chart A4 reports results for seven broad sectors, aggregating results for the full 113 industries of the model. The policy promotes positive deviations in output of all sectors. It is particularly favourable for Dwellings and Construction. As already discussed, these results can be understood as the joint effects of a productivity improvement (arising from lower compliance and administrative costs) and the program of rate equalisation and exemption removal. Hence we investigate two additional simulations: one in which compliance costs are reduced (Charts B1-B5) and one in which VAT rates are equalised and exemptions are removed (Charts C1C6). 


\subsection{The effects of lowering compliance and administrative costs}

Charts B1-B5 report the macroeconomic and sectoral effects of lower compliance costs. As discussed in Section 4, we model lower compliance costs as an improvement in primary factor productivity relative to basecase. With short-run real consumer wages sticky, the positive deviation in productivity generates a short-run positive employment deviation (Chart B1). Together with the positive deviation in productivity, this accounts for the initial positive deviation in real GDP. The real wage rises so long as employment remains above basecase. This accounts for the long-run movement of the employment deviation towards zero. Despite the return of employment to basecase, the growing positive capital deviation (Chart B1) ensures that the real GDP deviation remains just under 0.5 per cent throughout the period.

Capital stocks take time to adjust. Hence in the short-run, the positive deviations in both productivity and employment produce a positive deviation in the average rate of return. In Chart B2, this is expressed as a positive deviation in the average capital rental price relative to the investment price deflator. This explains the initial spike in the investment deviation (Chart B2). With real investment above basecase, the capital deviation grows through time. The capital deviation continues to grow until rates of return tend back to basecase. In Chart B2, this is apparent in the convergence of the deviations in the investment price deflator and average capital rental rate.

The short-run real private consumption deviation is just under 0.7 per cent (Chart B3). This exceeds the real GDP deviation by 0.3 percentage points. Our real consumption decomposition (Table 1, column 2) explains why. Since our consumption closure keeps real savings on its basecase path throughout the policy simulation (via E15), the real GDP effect (row 1, column 1, Table 1) requires the real consumption deviation to exceed the real GDP deviation. Together with the short-run spike in real investment, this causes the real GNE deviation to exceed the real GDP deviation. This pushes the real balance of trade towards deficit, apparent in Chart B4 as a short-run positive deviation in import volumes relative to export volumes. In Chart B4 we see the import deviation tracks the real GDP deviation quite closely. This is an activity effect: with GDP, real consumption and investment higher than basecase, import usage is also higher than basecase. With our macro closure allowing only limited scope for movements in the balance of trade, the strong positive import deviation requires that the export deviation also be positive. This accounts for the negative deviation in the terms of trade (Chart B4). This is an important factor in explaining why the long-run real consumption deviation is lower than the short-run deviation (compare columns 6 and 2, row 2, of Table 1). Another factor damping the long-run consumption deviation is foreign debt 
accumulation. With real savings held on its basecase path, the investment responsible for the positive capital deviation (Chart B1) is financed by foreign savings. In 2018, interest on this debt is worth 0.07 percentage points of the potential real consumption deviation (row 4, column 6, Table 1).

\subsection{Effects of rate equalisation and exemption removal alone}

Charts C1 - C6 report the macroeconomic consequences of equalising VAT rates at 8.3 per cent and removing discretionary exemptions. This has a favourable effect on real private consumption spending, lifting it by just over one quarter of a per cent (relative to basecase) throughout the simulation period (Chart C1). Columns (3) and (7) of Table 1 provide shortrun and long-run decompositions of the real consumption outcome. As we explain below, in the short-run, the positive consumption deviation arises from the positive terms of trade deviation. Favourable terms of trade is less important for the long-run consumption deviation (row 2, column 7, Table 1). The favourable long-run consumption deviation is due mainly to the positive deviation in real GDP (row 1, column 7, Table 1) offset by the need to finance foreign capital suppliers (row 4, column 7, Table 1).

A prominent feature of the macroeconomic consequences of our changes to VAT rates and exemptions is the strong short-run positive deviation in real investment relative to real GDP (Chart C1). This is due largely to reductions in VAT rates paid on inputs to dwellings construction. As discussed in Section 2, VAT paid on most inputs to capital formation is refunded. An important exception is dwellings construction. Inputs of construction services to dwellings investment are initially taxed at 10 per cent. Our policy of equalisation of VAT rates brings this rate to 8.3 per cent. In the short-run, this lowers the cost of dwellings capital formation. At the economy-wide level, this manifests as a fall in the price of investment relative to the GDP deflator (Chart C2). Since the negative deviation in the price of investment is greater than the negative deviation in the capital rental rate (Chart $\mathrm{C} 2$ ), the average rate of return deviation is positive. This accounts for the strong positive deviation in investment, and the resulting growing positive deviation in the capital stock (Chart C1).

The growing deviation in the capital stock accounts for the growing real GDP deviation (Chart C3). By 2018, real GDP is 0.16 per cent above basecase (Chart C3). Ceteris paribus, this lifts real private consumption by 0.26 per cent (row 1 , column 7 , Table 1 ). However the real GDP deviation is due largely to the positive capital deviation (Chart C3). Since we hold real savings on its basecase path, only the difference between the return on capital and the foreign cost of that capital is available for domestic consumption. The long-run cost of 
financing foreign capital reduces private consumption spending by 0.09 percentage points (row 4, column 7, Table 1).

Note that in the first year of the simulation, the real GDP deviation is near zero, despite a 0.10 per cent negative employment deviation and no change in the capital stock ${ }^{26}$ (Chart C3). The small short-run negative employment deviation is due to our assumption of short-run stickiness in the real consumer wage. Equalisation of VAT rates at a level that is revenue neutral in the presence of exemption removal involves a shift in the indirect tax load, away from production and investment and towards consumption. This causes the consumption deflator to rise relative to the GDP deflator. With real consumer wages sticky in the short-run, this generates a short-run positive deviation in the real producer wage, causing employment to fall relative to basecase ${ }^{27}$. Since wages represent approximately 52 per cent of Vietnam's GDP at factor cost, we might have expected the 2008 real GDP deviation to be approximately -0.05 per cent $(=-0.10 * 0.52)$, not 0 . The difference $(+0.05$ per cent) represents the small allocative efficiency gain from VAT rate equalisation.

In the short-run, with the real investment deviation greatly exceeding the real GDP deviation, the real balance of trade must move towards deficit relative to basecase (Chart C4). The resulting negative deviation in export volumes causes the terms of trade to improve relative to basecase (Chart C4). As our real consumption decomposition makes clear, the improvement in the short-run terms of trade accounts for much of the short-run positive deviation in real consumption (column 3, row 2, Table 1). However, not all of the terms of trade gain is attributable to the strong deviation in investment relative to real GDP. As we argue below, changes in exemptions also contribute to the positive terms of trade deviation.

Charts C5 and C6 report output deviations for seven broad sectors. Chart C5 reports the output deviations of the three sectors experiencing the largest positive output gains (dwellings, construction and mining). It also reports the deviation in the price to households of dwellings services. The effects of reducing the VAT rate on inputs to dwellings construction are clearly visible in the dwellings output and price deviations. Initially, reducing the VAT rate on inputs to dwellings construction has no effect on dwellings output. However it lifts the rate of return on new dwellings capital. This lifts output of the construction sector relative to basecase. With housing construction higher than basecase, the capital stock of the dwellings sector begins to rise relative to basecase. This accounts for the growing positive deviation in output of dwellings services (Chart C5). Over time, the fall in the construction cost of dwellings capital is passed through to consumers in the form of lower dwellings rental rates via an increase in the supply of dwellings capital. This accounts for the growing negative 
deviation in the price of housing (Chart C5) ${ }^{28}$. A decade after the reform, the rental price of housing is 1.6 per cent below basecase, and housing supply is 1.4 per cent higher than basecase. Revenue-neutral VAT rate equalisation thus materially advances a major element of Vietnam's development policy, promotion of low-cost housing ${ }^{29}$.

After dwellings and construction, mining is the sector next most favourably affected by rate equalisation and exemption removal (Chart C5). This reflects the removal of exemptions on exports of the mining sector. Via (E2), removal of exemptions on mining exports increases mining's refund factor ${ }^{30}$. Via (E3), this reduces the effective intermediate input taxes paid by the sector. This flows through to lower mining output prices. This accounts for the large real appreciation generated by rate equalisation and exemption removal (Chart C4). Since the deviation in aggregate export volumes is largely tied-down by the import volume deviation and the relative deviations in real GDP and real GNE, a large negative deviation in the relative export price of one commodity (mining in this case) requires real appreciation to crowd-out other exports. This accounts for the sustained positive deviation in the real exchange rate. The positive real exchange rate deviation peaks in the first years of the policy, when the positive deviation in real investment pushes the real balance of trade sharply towards deficit. To achieve this deficit, the real appreciation must be higher than that required simply to eliminate the effect on export prices of exemption removal. By crowding-out nonmining exports, the real appreciation contributes to the short-run real consumption deviation via improved terms of trade. However it also contributes to the short-run real consumption deviation via a reduction in the domestic currency value of foreign debt obligations. This effect is measured in row 6 of Table 1. It is strongest in the short-run, adding 0.05 percentage points to the 2008 real consumption deviation.

Chart C6 reports results for the four sectors that experience the lowest output deviations as a result of VAT rate equalisation and exemption removal. Both utilities and services sell substantial proportions of their output to households. Hence production in both sectors is stimulated by the positive real consumption deviation. Expansion of utilities output is also promoted directly by VAT rate equalisation: the VAT rate on electricity and gas falls from 10 per cent to 8.3 per cent, promoting greater household consumption of electricity and gas.

VAT rate equalisation and exemption removal produce negative deviations in output of agriculture and manufactures. Both sectors are trade-exposed, and thus adversely affected by the real appreciation. The deviation in agricultural output is deepest in the first year of the policy. This is the year of strongest real appreciation (Chart C4). However, agricultural output slowly recovers, ending the period just below its basecase level (Chart C6). Manufactures 
output also experiences a negative deviation in the first year, but does not recover (Chart C6). The pattern of trough and gradual recovery in agriculture's output can be traced to an expansion in sales by agriculture to domestic food manufacturing. The policy includes removal of exemptions on sales by some food manufacturers, thus lowering their post-tax input costs. The policy also reduces the VAT rates for other food products from 10 to 8.3 percent $^{31}$. Together, these changes promote output expansion as price-sensitive agents substitute towards the now-cheaper domestically produced food. The positive deviation in the output of food manufacturing (not shown) stimulates domestic sales of agriculture, a major supplier to domestic food manufacturing industries. Despite a positive deviation in output of food manufacturing industries, the aggregate output deviation for the manufacturing sector is negative (Chart C6). Outside of the food manufacturing industries, no other industries within the manufacturing sector benefit from exemption-related reductions in tax-inclusive input costs. This leaves them exposed to real appreciation. The net negative deviation in output of manufacturing is due to real-appreciation-induced negative deviations in output of such tradeexposed industries as machinery and equipment, TCF, metal products, and wood and paper products.

\section{CONCLUSIONS}

With their many commodities and agents, CGE models are well-suited to analysis of a complex tax like VAT. A detailed VAT modelling framework, such as that which we present in this paper, is important in CGE analysis of VAT issues for two reasons. First, it allows the model's tax theory to addresses the full details of the VAT system as implemented by tax authorities. Second, it facilitates correct representation of VAT payments in the model's database. Statistical agencies often get the latter wrong by assuming that all VAT falls on private consumption. Ensuring that the database is correct in this respect is essential if we are to have an initial solution to our CGE model that is consistent with our VAT tax theory. However, even in a CGE model without sophisticated VAT theory, correct representation of the distribution of indirect taxation in the model's database is important for welfare analysis. Measured welfare effects of policy change are influenced by the size and distribution of the model's indirect tax wedges. Hence we expect the framework we present in this paper will also be of value to those CGE model builders who, while perhaps not interested in detailed modelling of VAT, are nevertheless keen to ensure that their model's database accurately depicts the structure of indirect tax payments.

We apply our tax model to the Vietnamese VAT system. This system has been in place since 1999. Despite many amendments, it remains overly complex, with three rates and a 
large number of exemptions. We examine the consequences of a tax reform whereby the three rates are replaced with a single rate that is revenue neutral in the presence of simultaneous removal of many discretionary VAT exemptions. We find that VAT simplification advances Vietnam development goals. Real private consumption, our welfare measure, is increased by an average of 0.9 per cent relative to basecase. We distinguish the effects of compliance cost reduction and the effects of VAT rate equalisation and exemption removal. The latter contributes about one third of our welfare gain, largely via a reduction in the rate of indirect taxation on capital accumulation. One effect of reducing indirect taxes on investment is promotion of housing supply. By 2018 our VAT policy lifts the stock of housing by 1.4 per cent and lowers the price of housing by 1.6 per cent. Lower compliance and administrative costs account for about two-thirds of our welfare gain. Our estimate of the fall in compliance and administrative costs arising from VAT simplification is illustrative, but plausible. We hope our estimate will stimulate interest in a more detailed study of VAT compliance and administrative costs for Vietnam. 
Chart A1: Real GDP, employment and the capital stock (\% deviation from basecase)

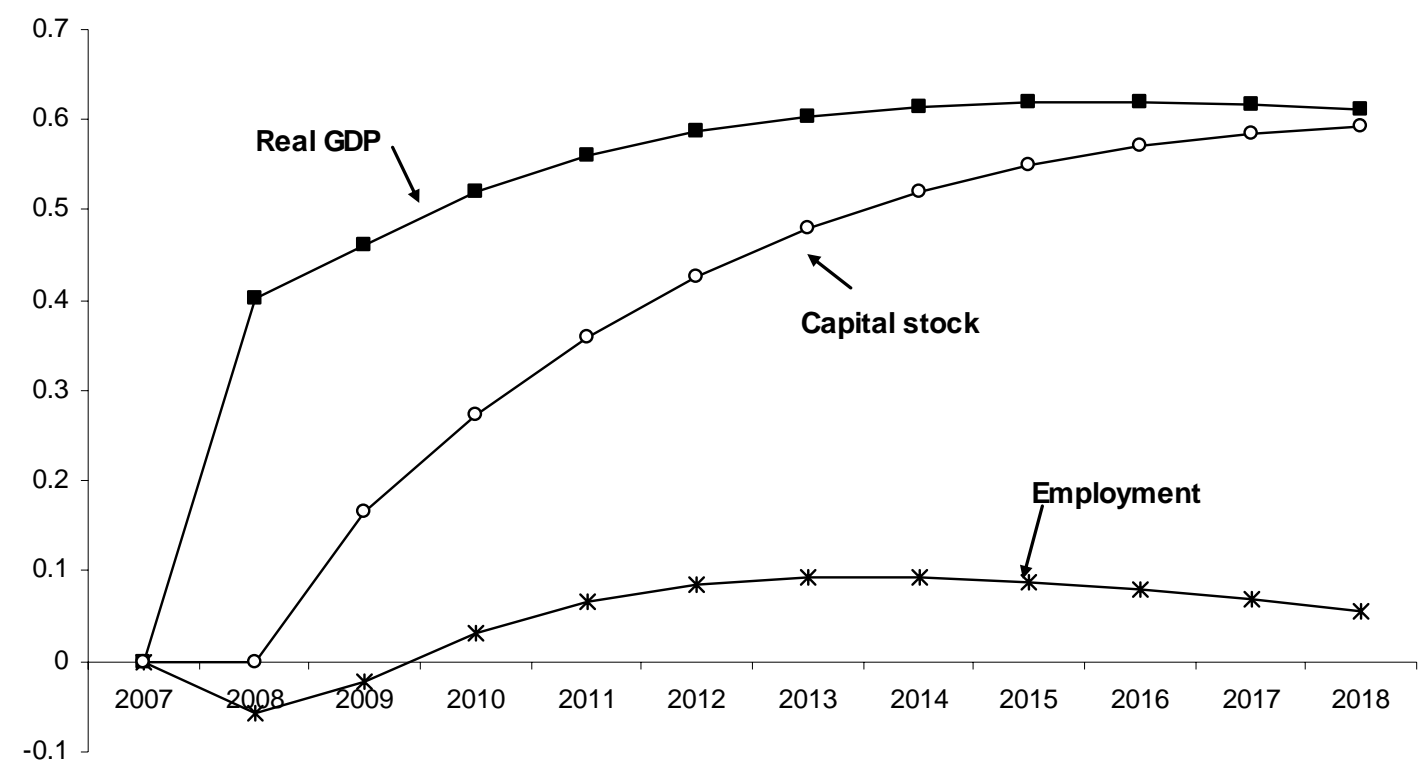

Chart A2: Real investment, private consumption and GDP (\% deviation from basecase)

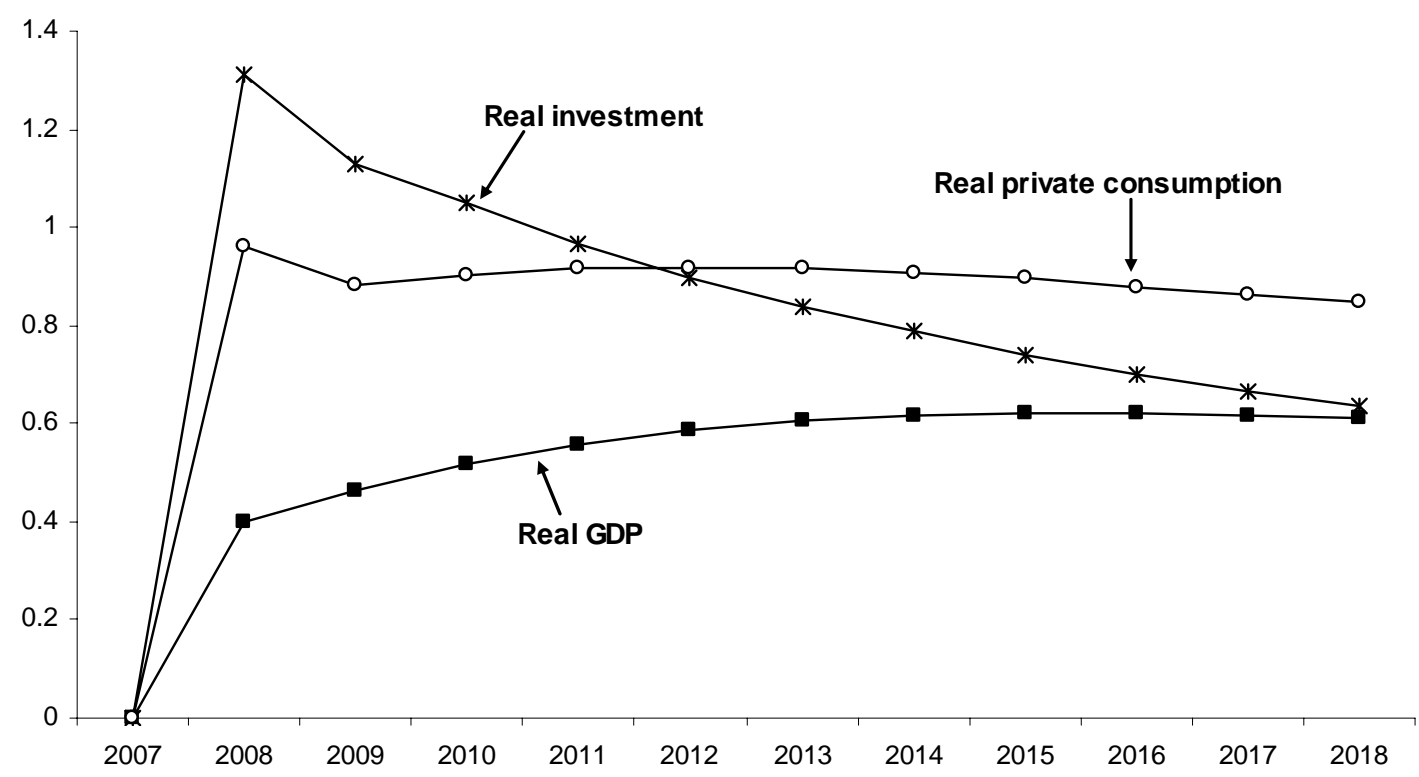


Chart A3: Export and import volumes and the terms of trade (\% deviation from basecase)

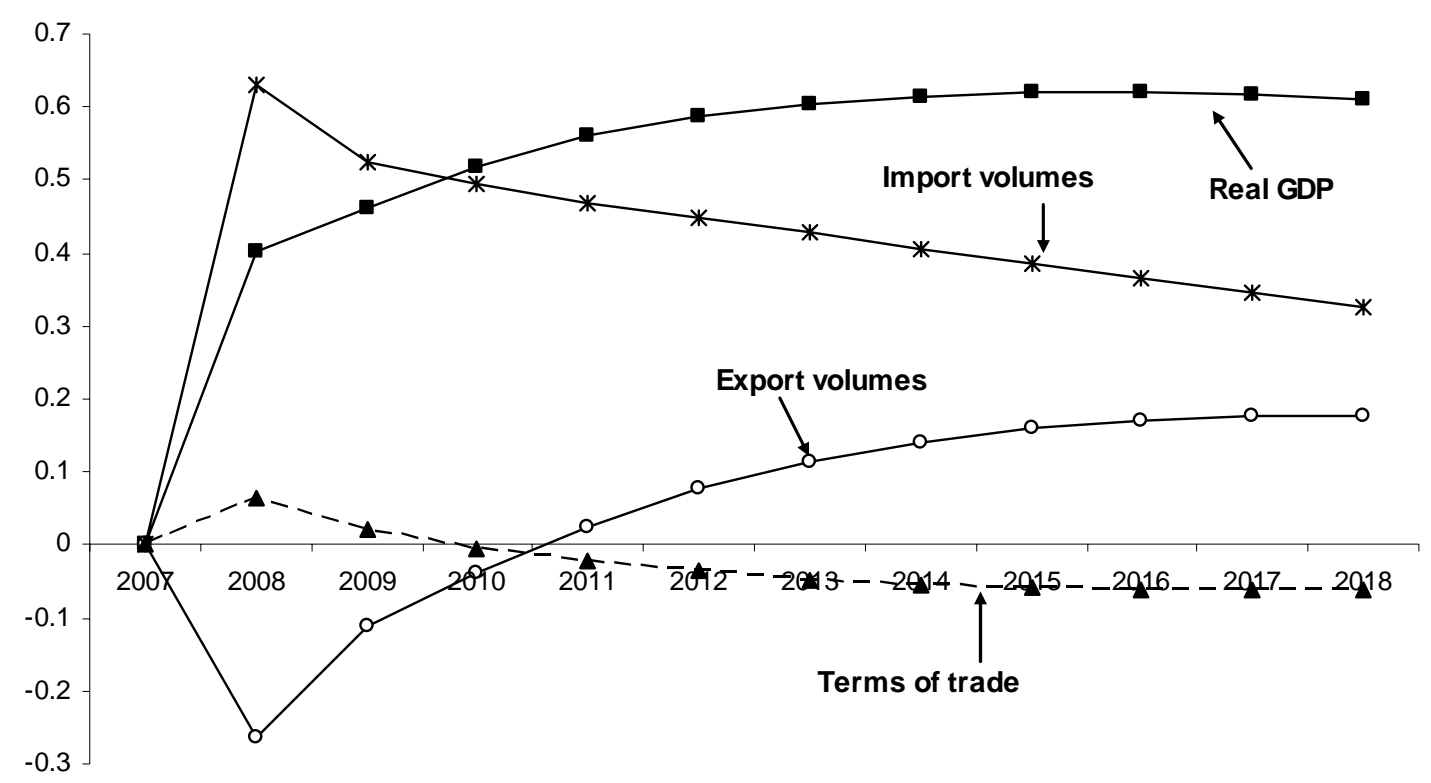

Chart A4: Sectoral output (\% deviation from basecase)

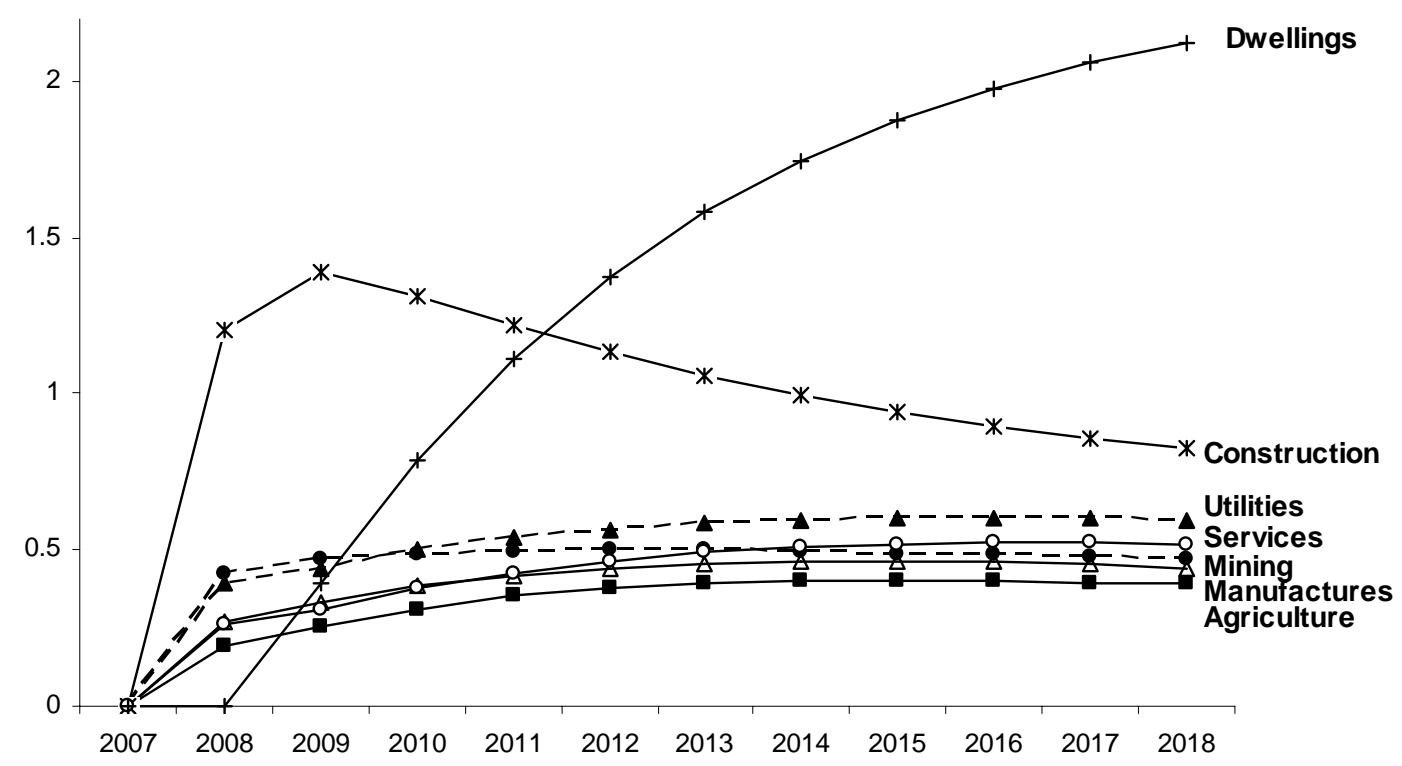


Chart B1: Real GDP, employment, capital and real wage. Compliance costs only. (\% deviation from basecase)

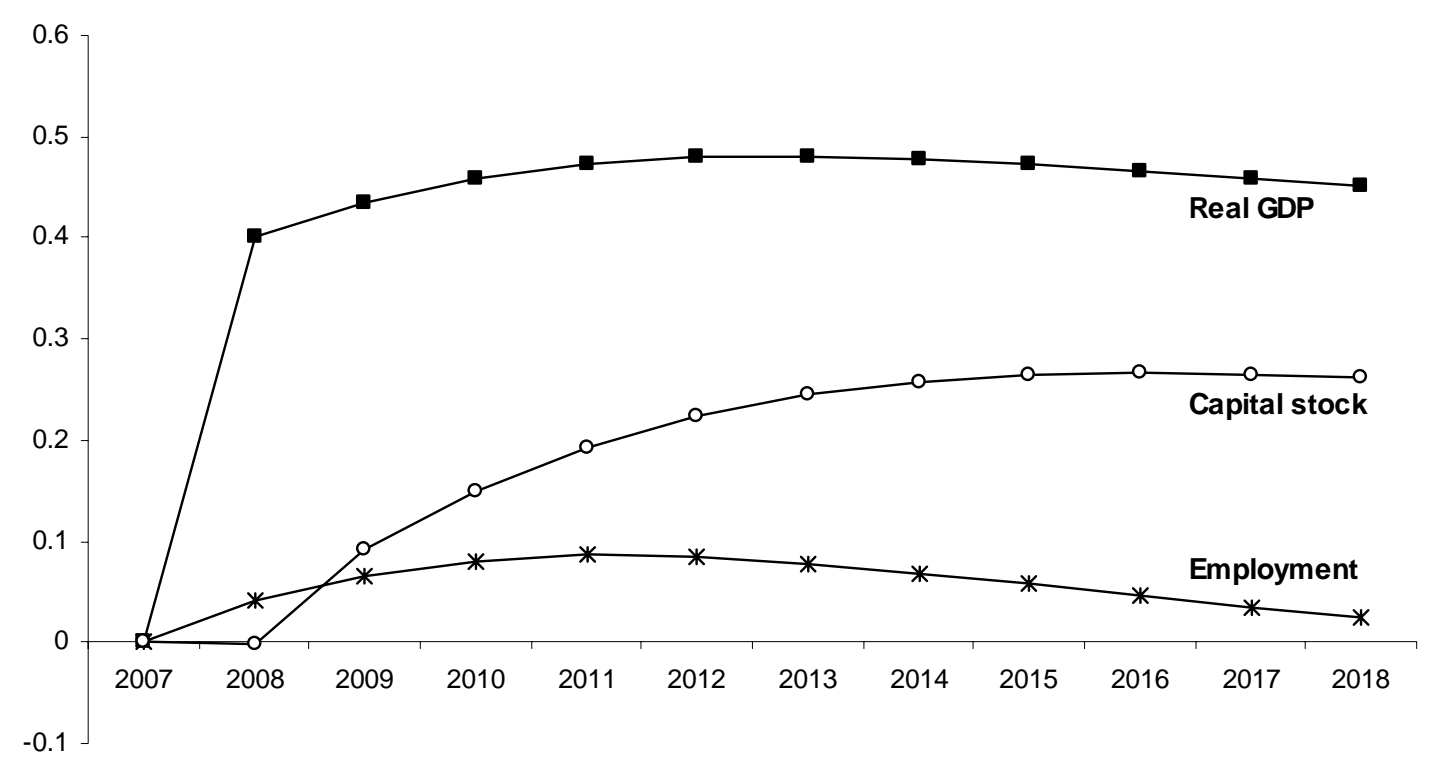

Chart B2: Rates of return and real investment. Compliance costs only. (\% deviation from basecase)

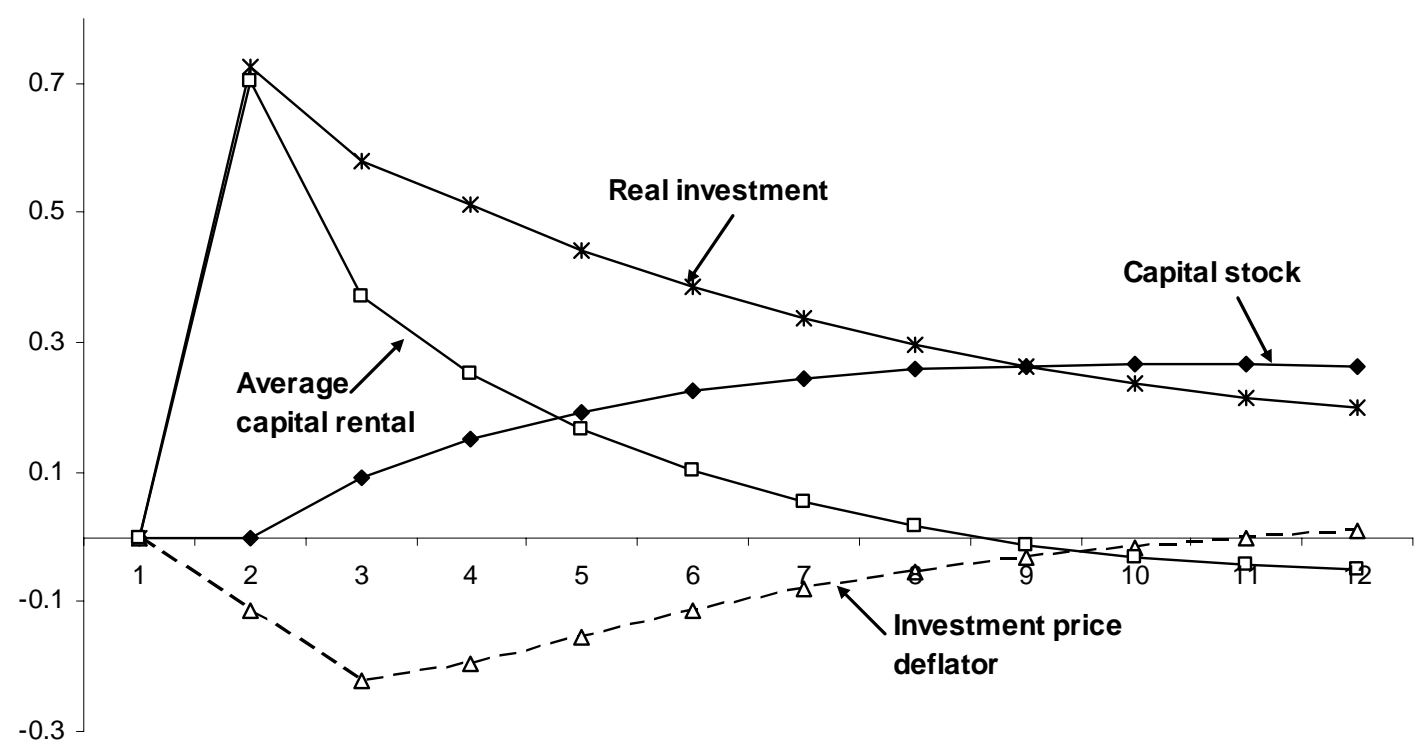


Chart B3: Real private consumption, investment and GDP. Compliance costs only. (\% deviation from basecase)

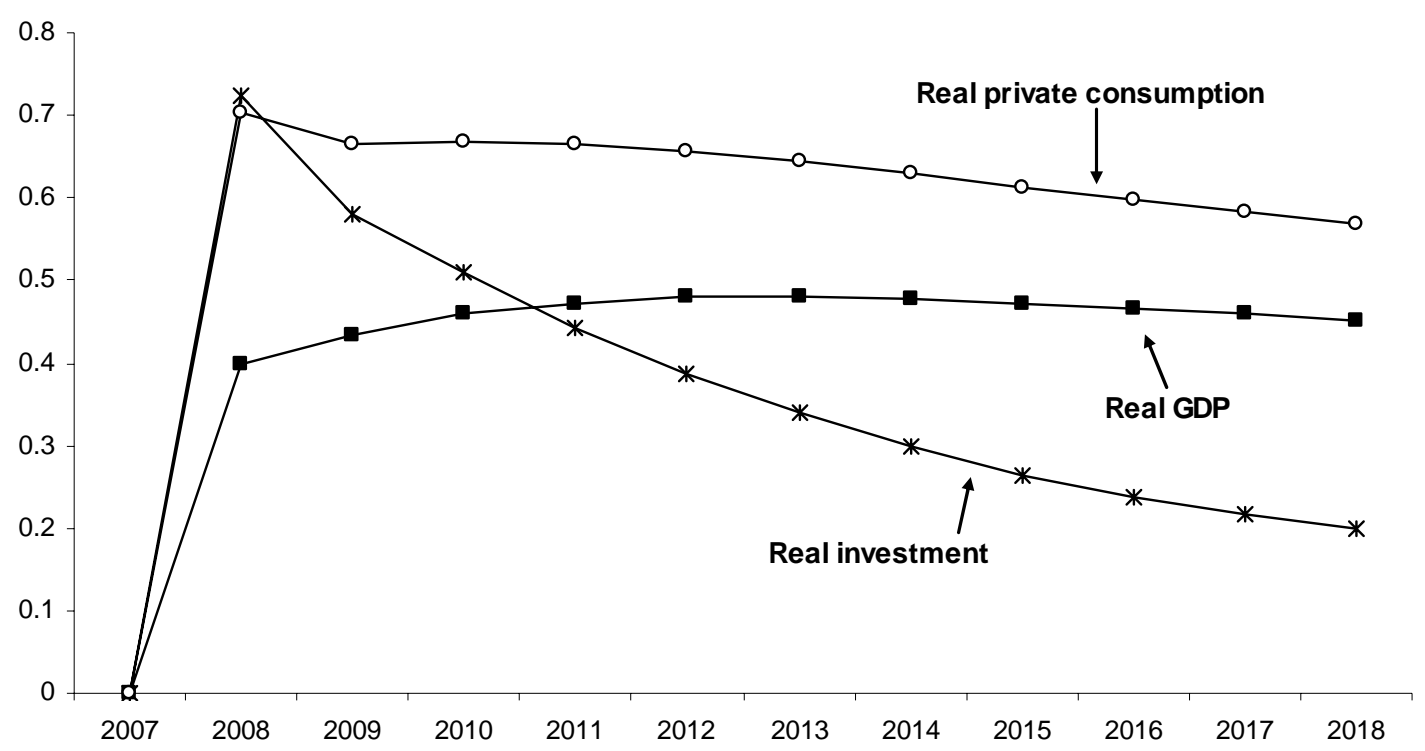

Chart B4: Export volumes, import volumes and the terms of trade. Compliance costs only. (\% deviation from basecase)

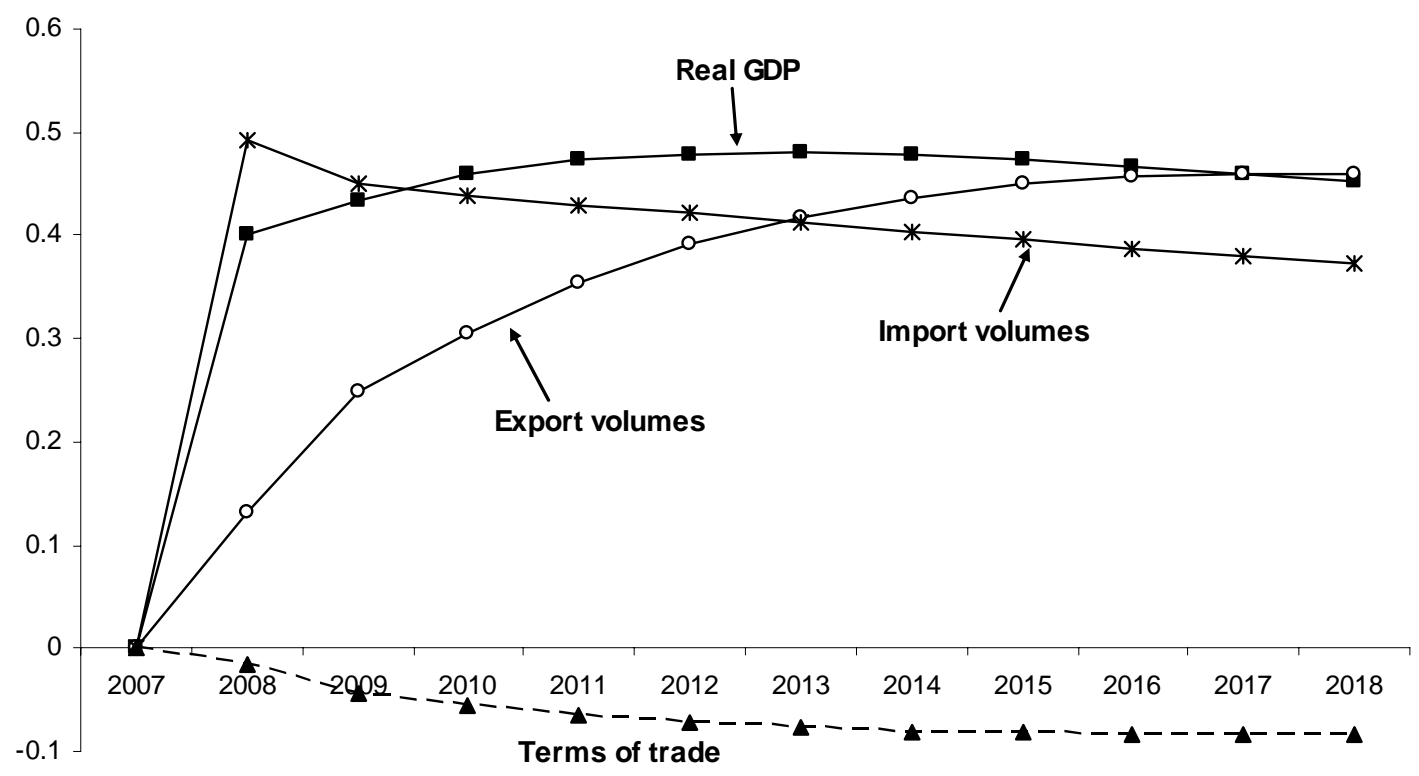


Chart B5: Sectoral output. Compliance costs only. (\% deviation from basecase)

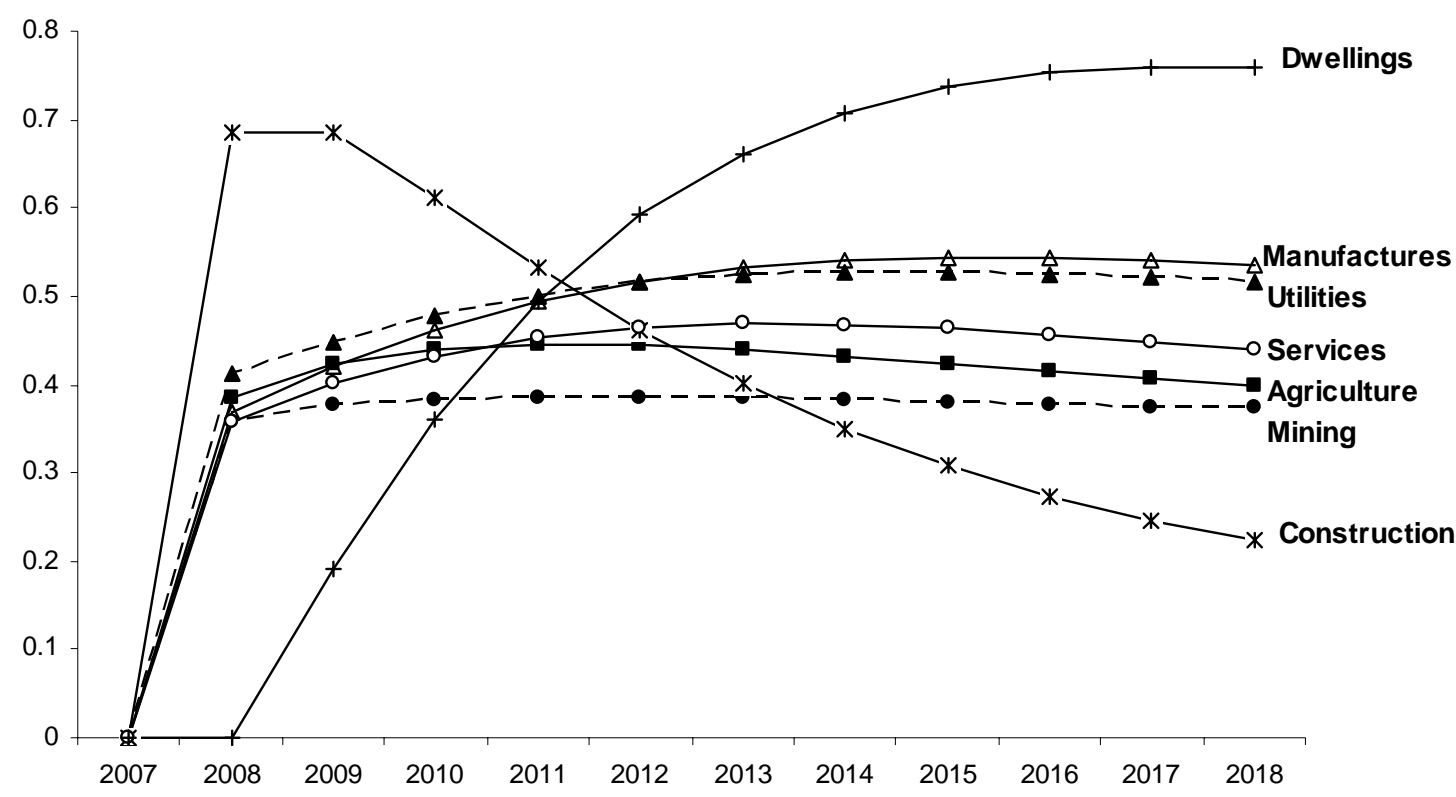

Chart C1: Real private consumption, investment and GDP. VAT rate equalisation and exemption removal only. (\% deviation from basecase)

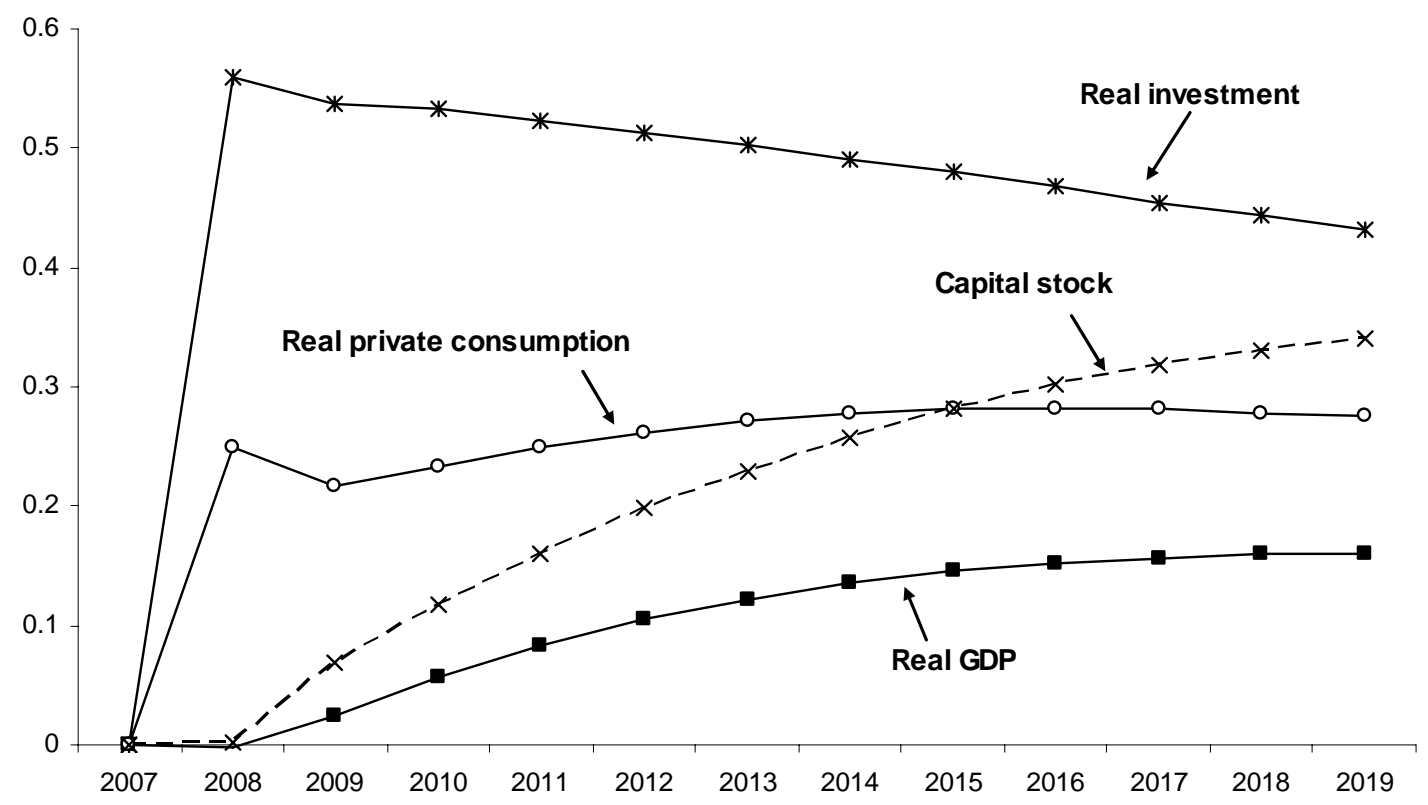


Chart C2: Rates of return and real investment. VAT rate equalisation and exemption removal only. (\% deviation from basecase)

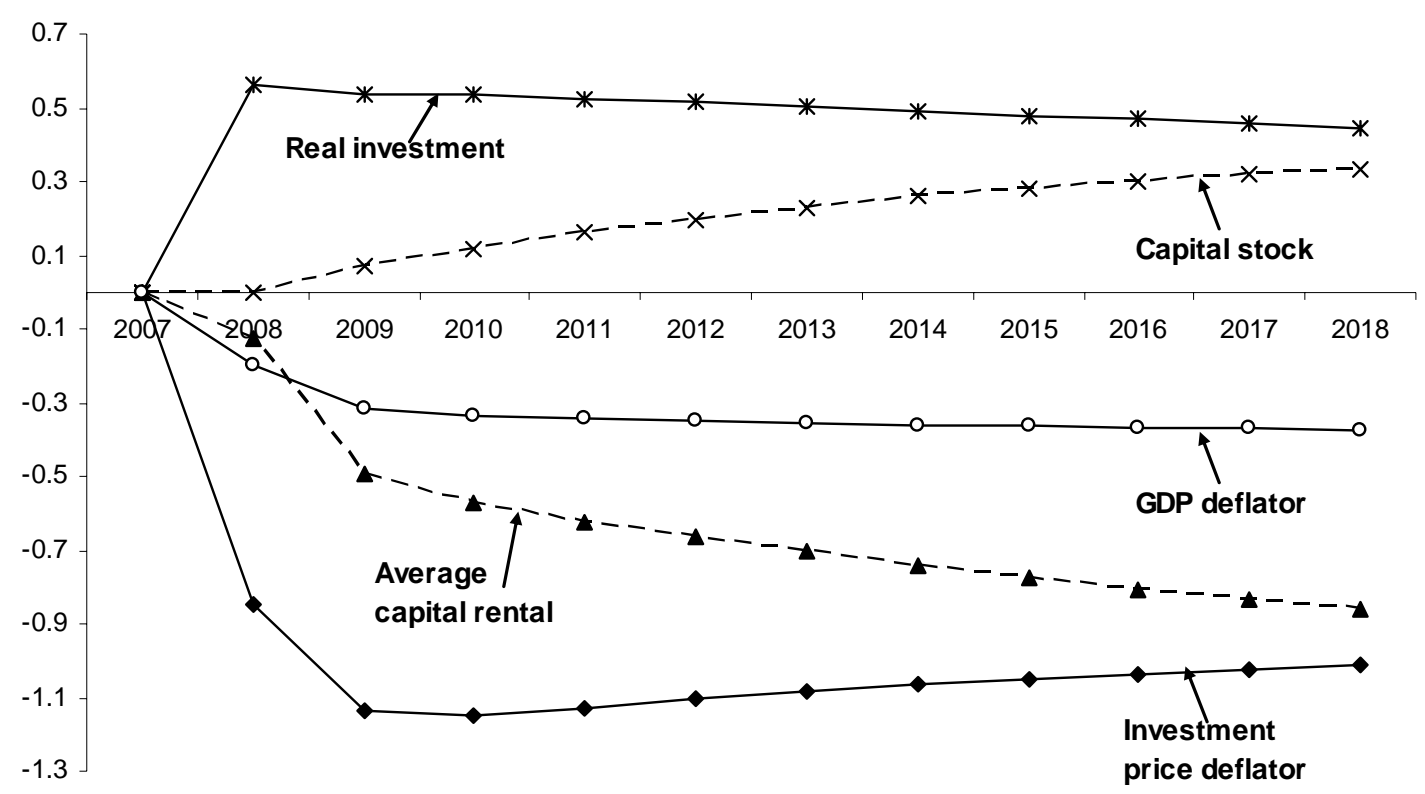

Chart C3: Employment, capital and real GDP.. VAT rate equalisation and exemption removal only. (\% deviation from basecase)

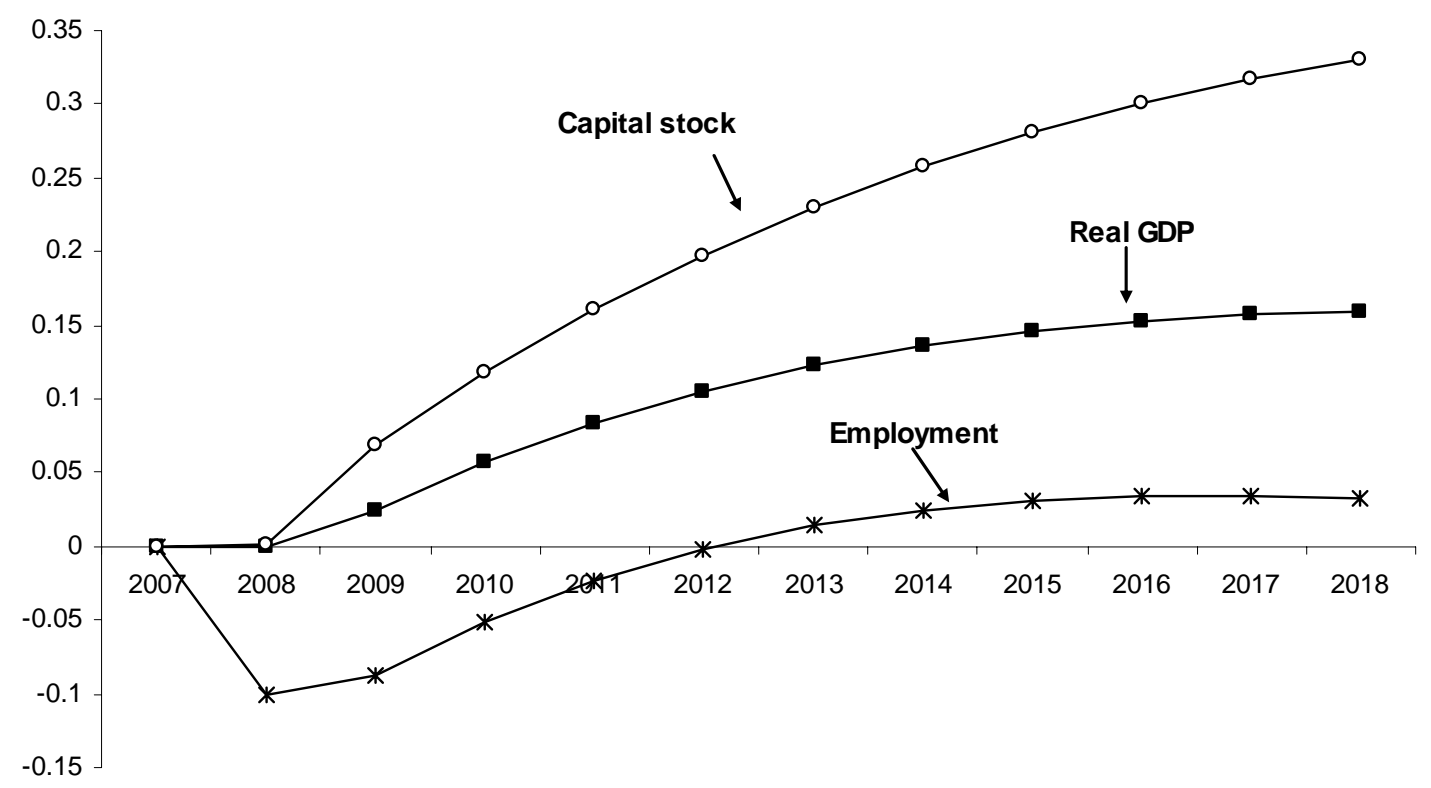


Chart C4: Export volumes, import volumes and the terms of trade. VAT rate equalisation and exemption removal only. (\% deviation from basecase)

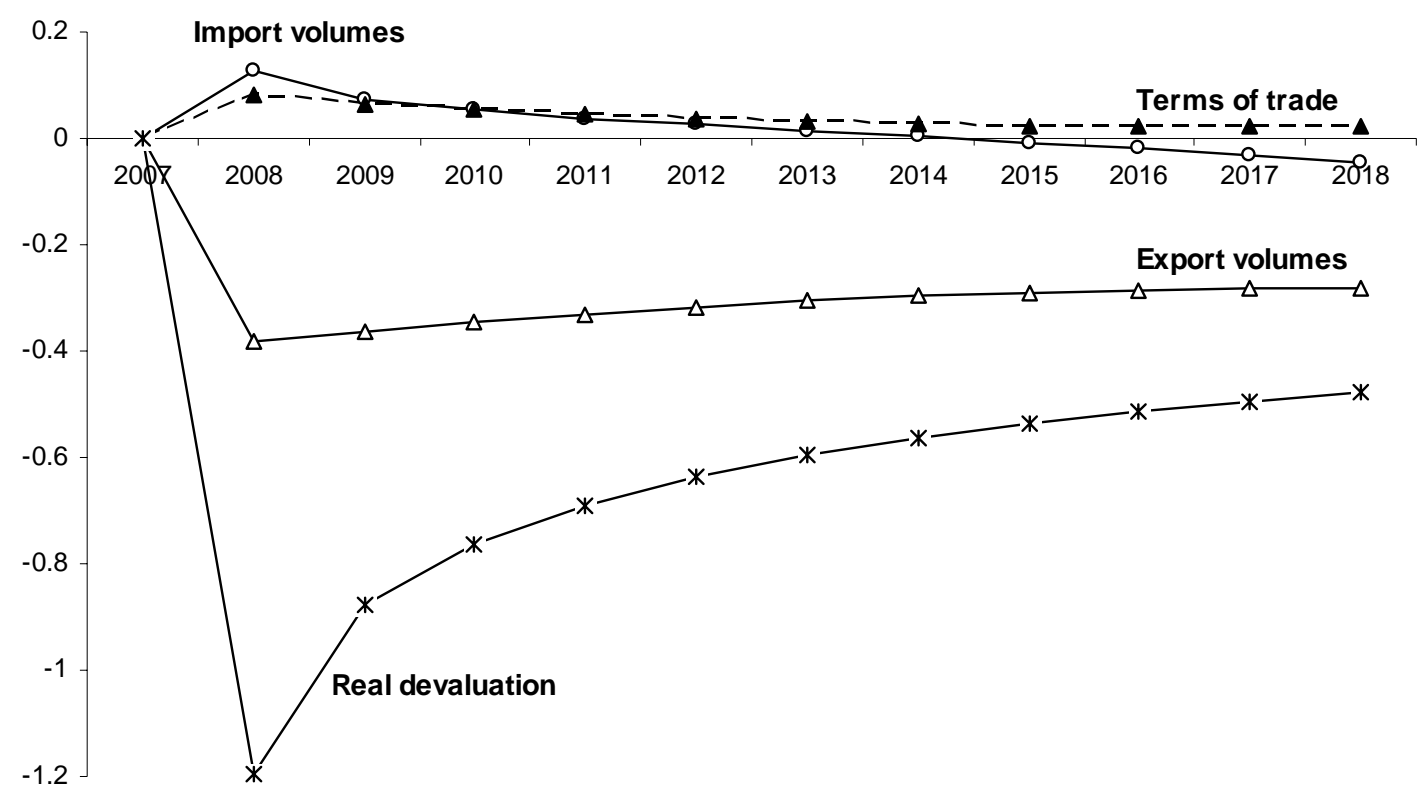

Chart C5: Output of the top three sectors, and the price of dwellings services. VAT rate equalisation and exemption removal only. (\% deviation from basecase)

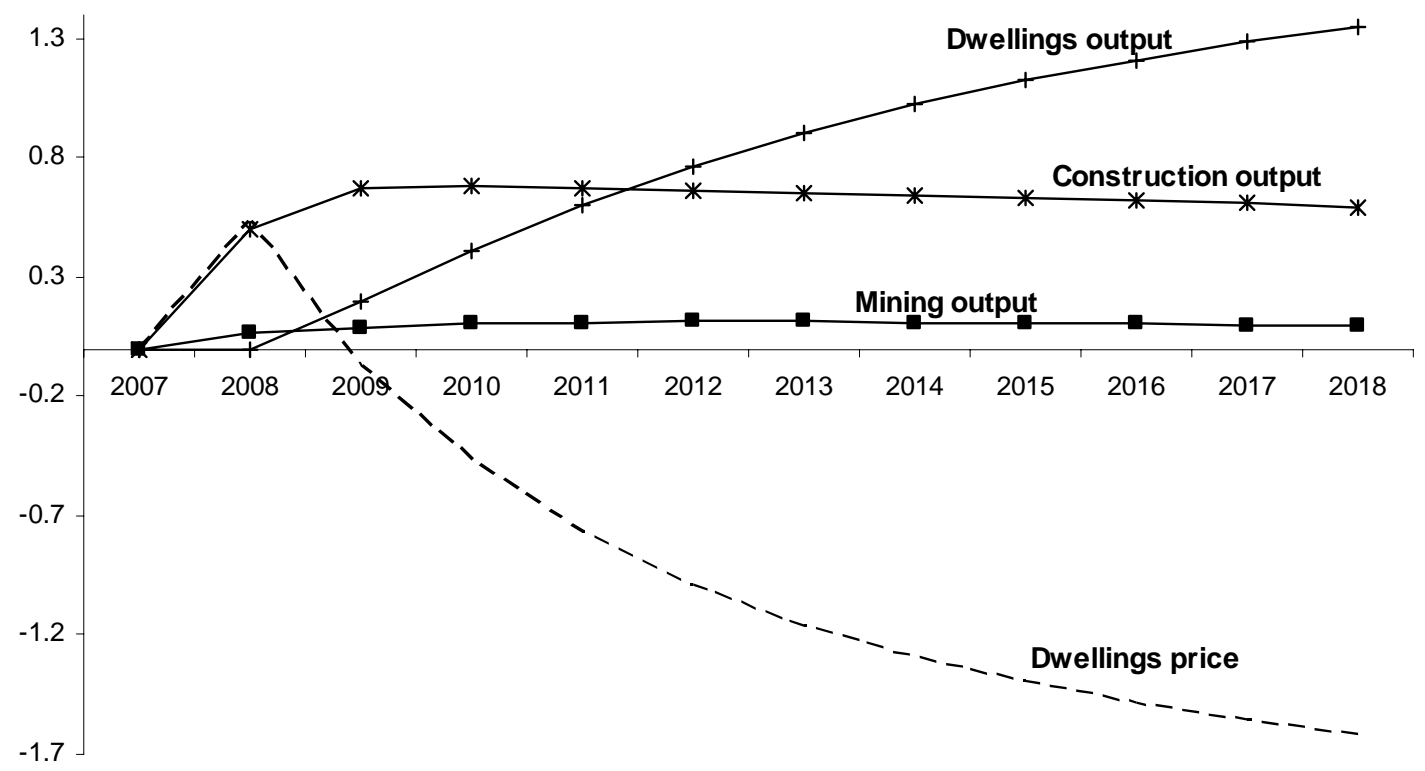


Chart C6: Output of the bottom four sectors. VAT rate equalisation and exemption removal only. (\% deviation from basecase)

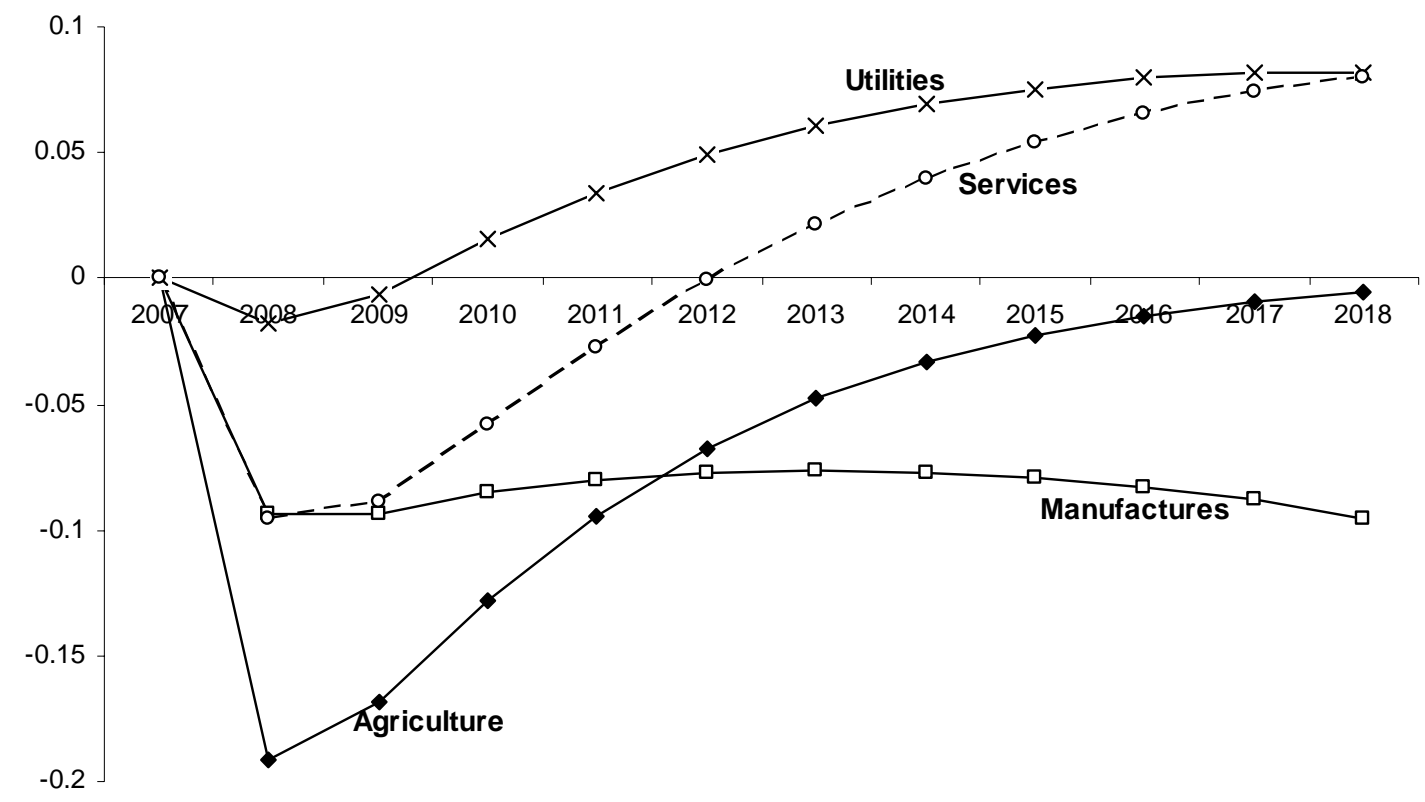




\section{REFERENCES}

Ballard, C. L., Scholz, J. K., Shoven J. B., 1987a. The Value-Added Tax: A General Equilibrium Look at Its Efficiency and Incidence. In: Feldstein (Ed.) The effects of taxation on capital accumulation, University of Chicago Press, Chicago, pp.105-107.

Ballard, C. L., Shoven J. B., 1987b. The Value-Added Tax: The Efficiency Cost of Achieving Progressivity by Using Exemptions. In: Boskin, M.J (Ed.) Modern developments in public finance: Essays in honor of Arnold Harberger, Blackwell, New York and Oxford, pp.109-129.

Bird, R. M., Gendron, P.-P., 2007. The VAT in Developing and Transitional Countries, Cambridge University Press, Cambridge.

Cnossen, S., 1998. Global Trends and Issues in Value Added Taxation. International Tax and Public Finance 5, 399-428.

Dixon, P. B., Rimmer, M. T., 1999. 'Changes in indirect taxes in Australia: a dynamic general equilibrium analysis’. The Australian Economic Review, 32(4), 327-48.

Dixon, P. B., Rimmer, M. T., 2002. Dynamic General Equilibrium Modelling for Forecasting and Policy: A Practical Guide and Documentation of MONASH, Contributions to Economic Analysis series, Vol. 256, North Holland, Amsterdam.

Ebrill, L., M., Keen, M., Bodin, J.-P., Summers, V., 2001. The modern VAT, International Monetary Fund, Washington, D.C.

Fehr, H., Rosenberg, C., Wiegard, W., 1995. Welfare Effects of Value-Added Tax Harmonization in Europe: A Computable General Equilibrium Analysis, Springer-Verlag, Berlin.

Fullerton, D., Henderson, Y.K., Shoven, J.B., 1984. A Comparison of Methodologies in Empirical General Equilibrium Models of Taxation, National Bureau of Economic Research, Inc.

General Statistics Office of Vietnam, 2004. Main results of establishment census of Vietnam 2002, General Statistics Office of Vietnam, online database. Retrieved Jan. 2008 from http://www.gso.gov.vn/default_en.aspx?tabid=481\&idmid=4.

General Statistics Office, (2009). " Gross domestic product at constant 1994 prices by economic sector". $\quad$ Retrieved Jan. 2009 from http://www.gso.gov.vn/default_en.aspx?tabid=468\&idmid=3\&ItemID=7381.

Giesecke, J.A., Tran, Hoang Nhi, 2008a. Compilation of the VIPAG database, Report by the Centre of Policy Studies, Monash University, to the Vietnamese Ministry of Finance, Project VIE/03/101 "Strengthening capacity in financial policy analysis for human development”, April 2008.

Giesecke, J.A., Tran, Hoang Nhi, 2008b. Theoretical Structure of VIPAG, Report by the Centre of Policy Studies to the Vietnamese Ministry of Finance, Project VIE/03/101 "Strengthening capacity in financial policy analysis for human development”, April 2008.

Gottfried, P., Wiegard, W., 1991. Exemption versus zero rating: a hidden problem of VAT, Journal of Public Economics, 46, 2007-328.

International Labour Organization, 2006. LABORSTA (Labour Statistics Database), Data on hours worked, employment, and participation rates, International Labour Organization, Geneva. Retrieved Mar. 2005 from http://laborsta.ilo.org. 
International Monetary Fund, 2007. Vietnam: 2007 Article IV Consultation-Staff Report; Staff Supplement and Statement; Public Information Notice on the Executive Board Discussion; and Statement by the Executive Director for Vietnam, IMF Country Report No. 07/387, International Monetary Fund, Washington, D.C.

Kehoe, P. J., Manreas, A., Noyolo, P.J., Polo, C., Sancho, F., 1988. A General equilibrium analysis of the 1986 tax reform in Spain. European Economic Review 32, 334-342.

Le Minh Tuan, 2003. Value Added Taxation: Mechanism, Design, and Policy Issues, Paper prepared for the World Bank course on Practical Issues of Tax Policy in Developing Countries, The World Bank, Washington D.C.

Marks, S. V., 2005. Proposed Changes to the Value Added Tax: Implications for Tax Revenue and Price Distortions. Bulletin of Indonesian Economic Studies, 41(1), 81-95.

McLure, C. E. J., 1990. Income Distribution and Tax Incidence under the VAT. In: Gillis, M., Shoup, C.S., Sicat, G.P. (Eds) Value Added Taxation in Developing Countries, The World Bank. Washington D.C., pp.32-40.

Ministry of Finance, 2006. Unique Implementation Needed for 2005 Enterprise Law. Hanoi, Vietnamese Ministry of Finance. Hanoi. Retrieved Jan. 2008 from http://www.mof.gov.vn/DefaultE.aspx?tabid=616\&ItemID=33792.

Ministry of Finance, 2007a. Circular on Value Added Tax providing guidelines for implementation of Decrees of the Government 148-2004-ND-CP dated 23 July 2004 and 156-2005-ND-CP dated 15 December 2005 implementing the Law on Value Added Tax and the Law on Amendments to the Law on Value Added Tax. Allen Arthur Robinson, Hanoi. Retrieved Jan. 2008 from http://www.vietnamlaws.com.

Ministry of Finance, 2007b. 'Enterprises' hidden costs', Online Electronics Newsletter, Issue 06 August 2007, Ministry of Finance, Hanoi. Retrieved Jan. 2008 from http://www.mof.gov.vn/ItemPrint.aspx?ItemID=45055.

National Assembly, 2003. "Law on amendment of the law on Value added tax." Retrieved Aug. 2007 from http://vbpq.mof.gov.vn/home.aspx.

Nguyen Minh Huong., 2007. The real situation of VAT policy and administration of VAT to household and individual businesses. Unpublished research report, General Department of Taxation, Hanoi.

Osaka Senken Ltd, 2006. "Vietnam: Minimum Wages Increasing in October" Asian Textile Business, Retreived Jan. 2008 from http://findarticles.com/p/articles/mi_qa5358/is_200610/ai_n21400020.

Policy Advisory Group - Ministry of Finance, 2007. 'The Vietnamese Input-Output Tables for the Year 2005', Project VIE/03/010 "Strengthening capacity in financial policy analysis for human development”, internal data.

PriceWaterhouseCooper and The World Bank, 2006. Paying Taxes: The Global picture, The World Bank, Washington D.C. Retrieved Jan. 2008 from http://www.doingbusiness.org/documents/DB_Paying_Taxes.pdf.

Salvail, M., 1994. The Goods and Services Tax: The Government's Administration Costs, Depository Services Programs, Government of Canada, Ontario. Retrieved Jan. 2008 from http://dsp-psd.pwgsc.gc.ca/Collection-R/LoPBdP/BP/bp377-e.htm. 
Socialist Republic of Vietnam, 2003. The Compehensive Poverty Reduction and Growth Strategy. Hanoi. Retrieved Jan. 2008 from http://siteresources.worldbank.org/INTVIETNAM/Overview/20270134/cprgs_fin alreport_Nov03.pdf.

Tait, A., 1988. Value Added Tax: International Practice and Problems, International Monetary Fund, Washington, D.C.

Toh, M.H., Lin Q., 2005 An evaluation of the 1994 tax reform in China using a general equilibrium model, China Economic Review 16, 246-270.

Tran Nam Binh, 2000. 'The Implementation Costs of the GST in Australia: Concepts, Estimates and Implications', Journal of Australian Taxation, 3 (5), 331-343.

Tran Nam Binh, 2001. 'Use and Misuse of Tax Compliance Costs' The Australian Economic Review, 34 (3), 279-290.

Vaillancourt, F., Clemens, J., 2008. 'Compliance and Administrative Costs of Taxation in Canada', in Clemens J. (Ed) The Impact and Cost of Taxation in Canada: The Case for Flat Tax Reform, The Fraser Institute, Canada. Retrieved Jan. 2008, from

http://www.fraserinstitute.org/Commerce.Web/product_files/ImpactAndCostOfTa xationInCanada2008.pdf.

Viet Phong, 2006 'Recruitment of senior employees: Character is the key', VN Express, Issue 8 February 2006. Retrieved Jan. 2008 from http://vnexpress.net/Vietnam/Kinh-doanh/Kinh-nghiem/2006/02/3B9E68BF.

Watanabe, S., Duong Thi Ninh, 2006. 'Indirect Tax Reform (VAT, SCT, and Import/Export Taxes', in The Final Report of the Joint Research Program on the Vietnamese Tax System, Japanese Ministry of Finance, Tokyo. 
${ }^{1}$ By mid 2006 there were around 140 countries with a VAT (Bird and Gendron, 2007).

${ }^{2}$ For comprehensive reviews of VAT systems, see Bird and Gendron, 2007; Ebrill et al., 2001; and Cnossen, 1998.

3 See for example Fullerton et al. (1984), McLure (1990, p.38), and Fehr et al.( 1995, pp. 39-40).

${ }^{4}$ See for example Tait (1988) and Ebrill et al. (2001).

${ }^{5}$ See for example Tran-Nam Binh (2000, 2001).

${ }^{6}$ The VIPAG (Vietnam Policy Advisory Group) model was developed in 2008 for the Vietnam Ministry of Finance by the Centre of Policy Studies, Monash University, under UNDP-funded project VIE/03/010.

${ }^{7}$ While the number of industries and commodities are identical in the model, $S O_{c, j}$ is not a diagonal matrix. On the contrary, the Vietnamese economy is characterised by a high level of multiproduction (Policy Advisory Group, 2007)

${ }^{8}$ In this example we also assume that textbooks are the only component of publishing that is VAT exempt.

${ }^{9}$ Note that $S O_{c, j}$ and $S S_{c, u}$ are coefficients, not variables. They are evaluated from the input-output data that forms part of the CGE model's initial solution.

${ }^{10}$ Gottfried and Wiegard (1991) note that this pattern of distribution of the VAT burden is well known among VAT experts. They provide an example using the 1984 input-output table for Germany, in which $63 \%$ of total VAT revenues fell on consumption expenditure, $21 \%$ on intermediate products and $16 \%$ on inputs to capital formation.

${ }^{11}$ In the long-run, employment is determined by demographic and labour market factors, such as the size of the labour force, participation rate, and the number of working hours. We assume these factors are unaffected by indirect tax reform.

12 We generate the basecase using the method developed by Dixon and Rimmer (2002). We use the following data and assumptions: (1) Actual GDP growth rates for the period 2006-2007 (GSO, 2009) and forecast growth rates for 2008-2012 (IMF, 2007). We assume that from 2012-2018 the economy continues to grow at its 2012 level; (2) An annual growth rate of 1.2 per cent for employment and population. This is an average of the forecast for the period by ILO (2006); (3) A growth rate of 0.14 per cent per annum in land supply, which we base on past trends.

${ }^{13}$ The consumption taxes include value added tax (VAT), special consumption tax, the gasoline fee, and registration tax. In 2005, total consumption tax revenue was VND 69,184.6 billion, of which VAT was VND 45,878 billion. Special consumption tax is levied only on some luxury goods, gasoline fee is levied on petroleum, and registration tax is levied primarily on sales to households of transportation means and dwellings.

${ }^{14}$ Another estimate of the time spent on VAT compliance by an average enterprise (MOF 2007b) is far higher, of the order of 1700 hours per year. This estimate has been credibly disputed by Vietnamese tax authorities. They argue it incorrectly includes time spent on invoice preparation and filing, activities independent of VAT. Hence we do not use this estimate.

15300 hours is equivalent to the employment of about 0.16 of a full-time accountant over a whole year (assuming 40 working hours per week, and 48 working weeks per year). An average wage for an accountant in 2005 was about 3 million VND per month (see Osaka Senken Ltd., 2006; and Viet Phong, 2006).

${ }^{16}$ Covering costs such as office space and equipment, payment for tax advice, accounting software upgrades, tax training, stationary and storage of invoices

${ }^{17}$ In our model, the ratio of non-labour costs to labour costs in the Accounting Services industry is 1.6:1. We use this as a proxy for the structure of the VAT compliance activity in each firm. However, 
since VAT compliance activities will share some facilities with other activities, we adopt a ratio of non-labour costs to labour costs for VAT compliance that is lower than 1.6:1, namely, 1:1.

${ }^{18}$ We base this on the Establishment Census 2002 estimate of the number of businesses (GSO, 2004), and the Ministry of Finance's (MOF, 2006) estimate of the number of new businesses registered during the period 2002-2005.

${ }^{19}$ Variable costs include both labour and some non-labour costs.

${ }^{20}$ Available from Establishment Census (GSO, 2004)

${ }^{21}$ We have discussed our estimates of private and public VAT costs with Vietnamese tax experts. They found our estimates plausible. They provided two additional observations to support our public administration cost estimate. First, researchers at the Vietnamese Institute of Financial Sciences drew our attention to the fact that the Vietnamese government allows taxation departments to use $2 \%$ of total tax revenues to cover their costs. There is evidence that the administration costs of VAT are higher than those of other taxes (see Brown and Vaillancourt, 1986, cited in Vaillancourt and Clemens 2007). Hence VAT administration costs are likely to be higher than $2 \%$ of VAT revenues. Second, an unpublished study by the Vietnamese General Department of Taxation (Nguyen Minh Huong, 2007) found that the administrative costs associated with collecting VAT from the million smallest enterprises registered for VAT comprised about 9-10\% of VAT collected from these enterprises. Since such costs fall with the size of a business, one VAT expert at the Vietnamese General Department of Taxation (Nguyen Minh Huong) viewed our 3.5\% estimate as plausible for the economy as a whole.

${ }^{22}$ Vaillancourt and Clemens (2008) founds that the compliance costs associated with VAT range between 3.7 and 7.3 per cent of total VAT collections. Expressed as a proportion of GDP, these costs represent 0.16 per cent of UK GDP, 0.44 per cent of New Zealand GDP, and 0.30 per cent of Sweden's GDP. Tran-Nam Binh (2000) estimates the recurrent compliance costs of Australia's VAT at about 8 per cent of 2000/01 VAT revenue. This represented about 0.30 per cent of Australian GDP.

${ }^{23}$ To simplify, assume that GDP is the same as GNDI. Then a typical closure for consumption spending is: $\mathrm{P}_{C} \mathrm{X}_{C}=\Phi \mathrm{P}_{\mathrm{GDP}} \mathrm{X}_{\mathrm{GDP}}$, where $\mathrm{P}_{\mathrm{C}}$ is the price of consumption (public and private), $\mathrm{X}_{\mathrm{C}}$ is real consumption, $\Phi$ is the average propensity to consume, $\mathrm{P}_{\mathrm{GDP}}$ is the GDP deflator, and $\mathrm{X}_{\mathrm{GDP}}$ is real GDP. To simplify further, assume that trade is balanced.Then, rearranging for $\mathrm{X}_{\overparen{C}}$ we have $\mathrm{X}_{\mathrm{C}}=\mathrm{X}_{\mathrm{GDP}}$ $\left[\left(\mathrm{P}_{\mathrm{I}} / \mathrm{P}_{\mathrm{C}}\right)^{\mathrm{SI}}\right]\left[\left(\mathrm{P}_{\mathrm{X}} / \mathrm{P}_{\mathrm{M}}\right)^{\mathrm{ST}}\right]$ where $\mathrm{P}_{\mathrm{I}}$ is the investment price deflator, $\mathrm{P}_{\mathrm{X}}$ is the export price deflator, $\mathrm{P}_{\mathrm{M}}$ is the import price deflator, and $\mathrm{S}_{\mathrm{I}}$ and $\mathrm{S}_{\mathrm{T}}$ are the shares of investment and trade in GDP respectively. From this equation we see that a consumption/GDP (or consumption GNDI) link will see real consumption fall if the price of investment falls relative to the price of consumption.

${ }^{24}$ Where investment is defined to include both gross fixed capital formation and additions to stocks.

${ }^{25}$ We can see that interaction between the two sets of shocks is low, since the values in residual columns (4) and (8) are very small.

${ }^{26}$ We assume that movements in capital follow movements in investment with an average half-year lag. Since the changes in VAT rates and exemptions occur in 2008, capital stocks do not begin adjusting until 2009.

${ }^{27}$ The risk of short-run employment loss from a rise in consumption taxation is also identified in Dixon and Rimmer (1999). They show that the possibility of employment loss during the transition to the new tax rate can be reduced by promoting after-tax wage bargaining and delivering a labour tax cut calibrated to compensate for the tax-induced rise in consumer prices.

${ }^{28}$ The deviation in the price of housing is positive in the first year of the simulation because the real consumption deviation is positive in this year, increasing demand for housing services. However the supply of housing stocks have not yet had time to begin adjusting upwards.

${ }^{29}$ In aiming to meet the United Nations Millenium Development Goals, an important element of the Vietnamese government's Comprehensive Poverty Reduction and Growth Strategy (Socialist Republic of Vietnam, 2003) is affordable housing development for low income people in urban areas and areas affected by natural calamity (such as flood-prone regions of the Mekong Delta).

${ }^{30}$ Vietnamese VAT laws stipulate that exports of mining products are exempt from VAT. This seems unusual, since exports have zero VAT rates. Our discussions with Vietnamese tax authorities confirmed that mining is input-taxed to the extent that it exports, and that this is an aim of the policy. 
The mining sector in Vietnam is heavily export-oriented, exporting 88.6 percent of its output (mainly crude oil and gas). Our calculations show that in 2005 the effective VAT rate on intermediate inputs to mining production was 6.2 per cent, and revenues from this source comprised 2.3 per cent of total VAT revenue.

31 Among 65 industries comprising the Manufactures sector, 14 belong to the food processing sector. Partial exemptions apply to meat, fruit and vegetables, and seafood. The ten per cent rate applies to many other food products, such as dairy products, oils and fats, bakery and confectionary, alcohol and wine, beer, coffee, and tea. Only rice and sugar products are taxed at 5 per cent. 